\title{
Sedimentary record of a fluctuating ice margin from the Pennsylvanian of western Gondwana: Paraná Basin, southern Brazil
}

\author{
Fernando F. Vesely ${ }^{\mathrm{a}, *}$, Barbara Trzaskos ${ }^{\mathrm{a}}$, Felipe Kipper ${ }^{\mathrm{a}}$, Mario Luis Assine ${ }^{\mathrm{b}}$, Paulo A. Souza ${ }^{\mathrm{c}}$ \\ a Departamento de Geologia, Universidade Federal do Paraná, Caixa Postal 19001, CEP 81531-980, Curitiba, PR, Brazil \\ b Departamento de Geologia Aplicada, Universidade Estadual Paulista, Av. 24-A, 1515, CEP 13506-900, Rio Claro, SP, Brazil \\ c Departamento de Paleontologia e Estratigrafia, Instituto de Geociências, Universidade Federal do Rio Grande do Sul, Caixa Postal 15001, CEP 91501-970, Porto Alegre, RS, Brazil
}

\section{A R T I C L E I N F O}

\section{Article history:}

Received 2 May 2015

Received in revised form 28 June 2015

Accepted 30 June 2015

Available online 7 July 2015

Editor: J. Knight

\section{Keywords:}

Late Paleozoic Ice Age

Glacial record

Ice marginal

Deglaciation

Itararé Group

\begin{abstract}
A B S T R A C T
The Paraná Basin is a key locality in the context of the Late Paleozoic Ice Age (LPIA) because of its location east of the Andean proto-margin of Gondwana and west of contiguous interior basins today found in western Africa. In this paper we document the sedimentary record associated with an ice margin that reached the eastern border of the Paraná Basin during the Pennsylvanian, with the aim of interpreting the depositional environments and discussing paleogeographic implications. The examined stratigraphic succession is divided in four stacked facies associations that record an upward transition from subglacial to glaciomarine environments. Deposition took place during deglaciation but was punctuated by minor readvances of the ice margin that deformed the sediment pile. Tillites, well-preserved landforms of subglacial erosion and glaciotectonic deformational structures indicate that the ice flowed to the north and northwest and that the ice margin did not advance far throughout the basin during the glacial maximum. Consequently, time-equivalent glacial deposits that crop out in other localities of eastern Paraná Basin are better explained by assuming multiple smaller ice lobes instead of one single large glacier. These ice lobes flowed from an ice cap covering uplifted lands now located in western Namibia, where glacial deposits are younger and occur confined within paleovalleys cut onto the Precambrian basement. This conclusion corroborates the idea of a topographically-controlled ice-spreading center in southwestern Africa and does not support the view of a large polar ice sheet controlling deposition in the Paraná Basin during the LPIA.
\end{abstract}

(C) 2015 Published by Elsevier B.V.

\section{Introduction}

The extent and timing of Late Paleozoic Ice Age (LPIA) glaciers across Gondwana have gained considerable attention in the past few years (e.g., Fielding et al., 2008; Lopéz-Gamundí and Buatois, 2010; Isbell et al., 2012; Limarino et al., 2014a). The traditional paleogeographic view of huge continental ice sheets spreading across the supercontinent is confronted by developing ideas that recognize several smaller ice caps and alpine type glaciers on topographic highs flowing diachronically to the different basins (Isbell et al., 2012; Limarino et al., 2014a). Additionally, there is increasing evidence for a subaqueous nature of thick diamictite-bearing successions once considered subglacial terrestrial deposits (e.g. Eyles and Eyles, 2000) and an ice-keel scouring origin for previously interpreted subglacial features (e.g. Woodworth-Lynas and Dowdeswell, 1994; Vesely and Assine, 2014), making a reevaluation of previous paleogeographic reconstructions necessary.

Most recent studies on late Paleozoic glacial deposits of southwestern Gondwana were focused on the Andean proto-margin of the

\footnotetext{
* Corresponding author.

E-mail addresses: vesely@ufpr.br (F.F. Vesely), barbaratrzaskos@ufpr.br (B. Trzaskos), felipekippergeo@gmail.com (F. Kipper), assine@rc.unesp.br (M.L. Assine), paulo.alves.souza@ufrgs.br (P.A. Souza).
}

supercontinent (mostly in Argentina) where superb exposures are favored by the present arid climate and mountainous landscape (LópezGamundí and Martínez, 2000; Kneller et al., 2004; Dykstra et al., 2006; Stark and Del Papa, 2006; Isbell, 2010; Gulbranson et al., 2013; Henry et al., 2014; Limarino et al., 2014b). In these areas, deposition took place in arc-related and foreland basins (Limarino et al., 2006; Spalletti et al., 2010) that were invaded by topographically constrained glaciers draining from ice caps on former mountain chains (e.g., Protoprecordillera). As a result of this high-relief glacial setting, a great portion of the deglacial deposits is found confined within paleovalleys or paleofjords deeply carved on the preglacial basement. Because of these characteristics, paleogeographic models derived from the Andean basins are difficult to apply in the interior segment of southwestern Gondwana where low relief, intracratonic sag and extensional basins were presumably influenced by larger and topographically less constrained ice lobes (e.g., Santos et al., 1996; Visser, 1996).

The eastern portion of the Paraná Basin in southern Brazil is a key locality in the context of the LPIA because of its former position adjacent to basins now located in southwestern Africa (Fig. 1). Although this area exposes a rich and well known collection of glacial features (e.g., Bigarella et al., 1967; Rocha-Campos, 1967; Gravenor and Rocha-Campos, 1983), none of the previous researchers gathered these features into an integrated stratigraphic framework necessary to 


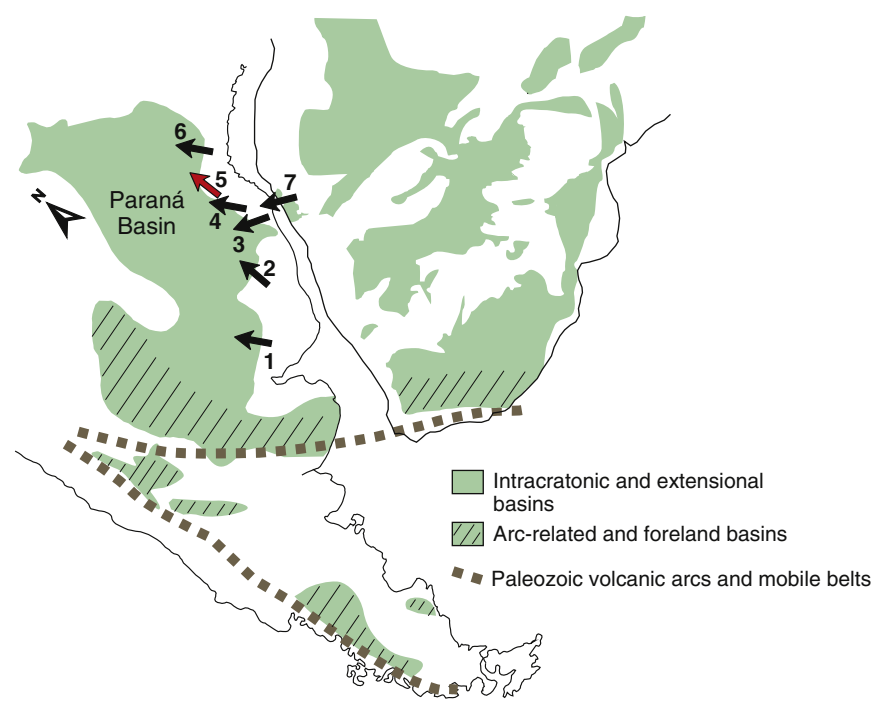

Fig. 1. Schematic view of southwestern Gondwana showing the main late Paleozoic basins (outcrop and subsurface) according to Catuneanu et al. (2005) and Isbell et al. (2012). Numbered arrows refer to published paleo ice-flow indicators according to the following references: 1, streamlined landforms on the Precambrian basement in Estancia Las Moras, Uruguay (Assine et al., 2010); 2, grooved and fluted surface on sandy diamictites in Cachoeira do Sul, Rio Grande do Sul (Tomazelli and Soliani, 1997); 3, striated and polished surface on the Precambrian basement in Alfredo Wagner, Santa Catarina (Rocha-Campos et al., 1988): 4, striated and polished surface on the Precambrian basement in São Bento do Sul, Santa Catarina (Barbosa, 1940); 5, striated and grooved surface on Devonian sandstones in Witmarsum region, Paraná (Bigarella et al., 1967); 6, roches moutonnées in Salto, São Paulo (Almeida, 1948); 7, roches moutonnées and crescentic gouges on Precambrian rocks in Huab and Kunene areas (northwestern Namibia) according to Frakes and Crowell (1970). The red arrow identified with number five is located in the area of the present study.

reconstruct the local glacial history and to discuss its paleogeographic implications. In this paper we document in detail this stratigraphic succession from several sections recorded in the eastern portion of the basin in southeastern Paraná State, south Brazil, in order to illustrate facies architecture and depositional settings associated with deglaciation and to discuss its significance for LPIA deposits in the cratonic domain of western Gondwana.

\section{Geological setting and previous work}

The Paraná Basin is a large Paleozoic-Mesozoic basin developed entirely on the intracratonic domain of western Gondwana (Figs. 1, 2). Because of being relatively far from any Phanerozoic orogenic belt, tectonic structures observed in the basin are essentially of brittle regime, mainly fractures and faults associated with extensional and strike-slip reactivations of basement shear zones and Mesozoic magmatism (e.g. Milani, 2004). The late Paleozoic stratigraphic interval of the basin is up to $2300 \mathrm{~m}$ thick and is bounded by widespread unconformities associated with major tectonic readjustments in the intracratonic domain (Milani, 2004). It comprises three major lithostratigraphic units named, from base to top, Itararé, Guatá and Passa Dois groups. The glacially influenced deposits, which extend for about $1600 \mathrm{~km}^{2}$ throughout the basin, including the outcrop belt and the subsurface, are contained within the late Bashkirian to early Sakmarian Itararé Group (França and Potter, 1991; Holz et al., 2010). The bulk of the stratigraphic record of the Itararé Group is of glacially influenced, marine deposits such as dropstonebearing mudstones, mass-transport diamictites with faceted and striated clasts and thick sandstones constituting outwash fans, deltas and turbidite lobes (Rocha-Campos, 1967; Rocha-Campos and Rosler, 1978; Gravenor and Rocha-Campos, 1983; França and Potter, 1991; Eyles et al., 1993; Santos et al., 1996; Vesely and Assine, 2006; Rocha-Campos et al., 2008). Terrestrial glaciogenic deposits, including diamictites interpreted as tillites, seem to be restricted to the lowermost interval of the Itararé Group (e.g., Rocha-Campos et al., 2008).
Efforts in subdividing the Itararé Group into formal lithostratigraphic units were performed in the outcrop belt (Schneider et al., 1974) and the subsurface (França and Potter, 1991), resulting in different formation names for each case. However, the vertical repetition of facies and lateral facies changes make it difficult to correlate such units using physical attributes alone (lithology and well logs). In terms of biostratigraphy, the Itararé Group encompasses three biozones of palynomorphs (Souza, 2006), which confirm that surface and subsurface sections are roughly equivalent in terms of age and that chronostratigraphic units can be traced for long distances across the basin. According to Vesely and Assine (2006), five unconformity-bounded sequences can be recognized in the Itarare Group and correlated in the central-eastern sector of the basin, including the outcrop belt in Paraná State and adjacent wells. All the five sequences have diamictites and dropstone-bearing fines as evidence for glacial influence and were interpreted as stacked deglaciation sequences in the sense of Visser (1997).

The Itararé Group rests unconformably on a Precambrian to early Paleozoic basement composed of igneous and metamorphic rocks as well as older sedimentary units of the Paraná Basin. As shown in Fig. 2, in the central-eastern part of the Paraná Basin the Itararé Group onlaps to the south in such a way that the lower levels thins and disappear southward. Because of this stratigraphic framework, the oldest records of Pennsylvanian glaciation occur only in Paraná and São Paulo states where the maximum thickness (up to $1000 \mathrm{~m}$ in outcrop) of the Itararé Group is observed. Because of post Paleozoic uplifting associated with the breakup of Gondwana, a significant part of eastern Paraná Basin was eroded, exposing its entire sedimentary-volcanic succession and part of the Precambrian basement. The configuration of the present outcrop belt is therefore controlled by a series of Mesozoic and Cenozoic arches and does not correspond to the margin of the basin during the late Paleozoic.

The pre-glacial substrate of the Itararé Group exhibits glacial landforms such as roches moutonées, whalebacks and striated pavements that indicate mean paleoice-flow towards the north and northwest (Fig. 1). According to the most accepted paleogeographic reconstructions these indicators would suggest that the ice that reached eastern Paraná Basin flowed from an ice cover located in highlands of Namibia (Windhoek highlands; cf. Visser, 1987; Santos et al., 1996). An ice spreading center located west of the Paraná Basin is still uncertain (Gesicki et al., 2002; Limarino et al., 2014a) since unequivocal subglacial landforms have not yet been discovered in that area and provenance studies are not yet available.

In the study area (Fig. 3), one of the first comprehensive reports on glacial rocks was provided by Maack (1946), which identified a reddish sandstone succession (Vila Velha sandstone) stratigraphically higher than the Devonian formations. Because of the existence of glacial diamictites immediately below the Vila Velha sandstone, the unit was placed by Maack (1946) in the Carboniferous and interpreted as a proglacial fluvial deposit. Bigarella et al. (1967) identified and mapped a series of glacially striated surfaces on the Devonian Furnas sandstones near Witmarsum, Palmeira and Porto Amazonas, which are underlain by sandy-silty diamictites interpreted as subglacial till deposits (Cancela tillite). These authors also observed the existence of intraformational (soft-sediment) striated/grooved surfaces in sandstones above the basal tillites, which led them to interpret two different episodes of glacier advance in a relatively thin (few tens of meters) stratigraphic succession. They inferred paleo ice-flow to the northwest based on kinematic criteria observed on striated surfaces and clast fabric of subglacial tillites.

França et al. (1996) reexamined the sand-rich Carboniferous succession exposed in the Vila Velha State Park and surroundings. Diverging from the previous interpretation of Maack (1946) they considered the local facies associations (including the Vila Velha sandsone and underlying deposits) as a result of subaqueous gravity flows in a glaciallyinfluenced marine environment, recognizing thin and thick-bedded turbidites and mass-flow diamictites. In a rhythmite interval between two 

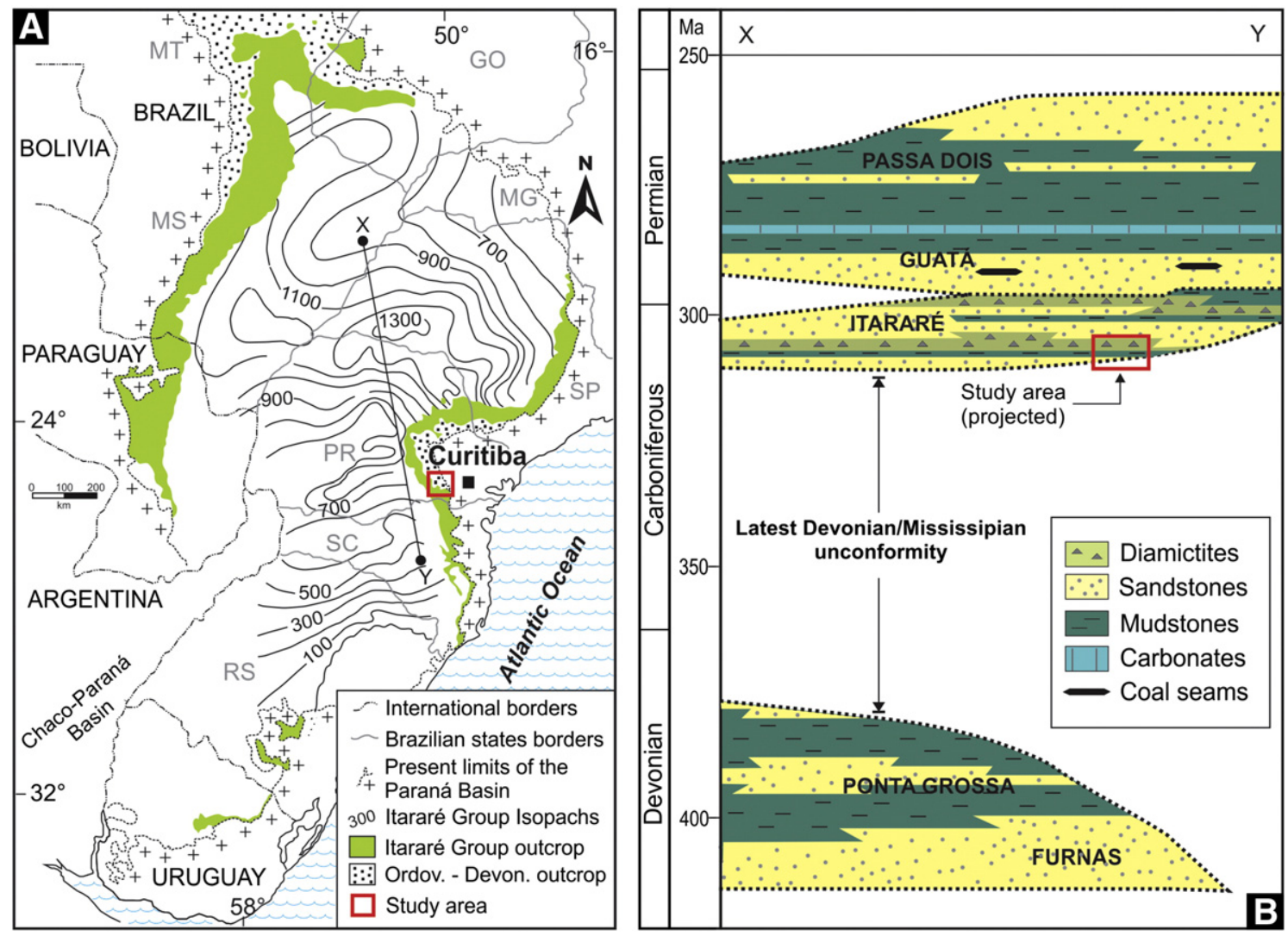

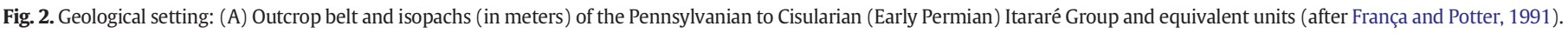

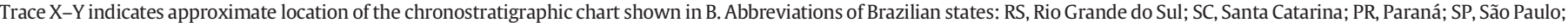

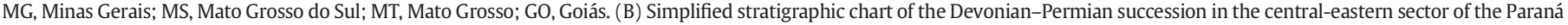
Basin based on outcrop and well log data (after Milani, 2004; Holz et al., 2010).

major sandstone successions the authors reported Pennsylvanian (Westphalian) palynomorphs and the presence of Tasmanites, which would indicate marine influence on the depositional environment. They correlated this marine interval with the Roncador shale, a radioactive marker previously mapped in the subsurface by França and Potter (1991).

All subsequent work in this sector of the basin focused on the reexamination of glacial surfaces that crop out near the localities of Purunã, Palmeira and Vila Velha (Fig. 3). Trosdtorf et al. (2005a) reported grooved surfaces on sandy-silty diamictite (lodgement tillite) at Purunã. According to the authors the structures were generated by ploughing of subglacial sediments during a single event of ice advance into a water body. The succession of mudstones and sandstones that sharply overlies the tillites was interpreted as deltaic and would record a rapid retreat of the ice margin.

Vesely and Assine (2002) noted that a great part of the striated surfaces found on sandstones were not formed on the Devonian Furnas Formation as considered by Bigarella et al. (1967), but they are rather placed in closely spaced, different stratigraphic levels in Carboniferous sandstones of the lower Itararé Group, being thus soft-sediment surfaces formed on unconsolidated sands. Trosdtorf et al. (2005b) interpreted these soft-sediment striated surfaces as grounding-line lineations produced by a tidewater glacier, which would indicate multiple advances of the ice margin. Subsequently, Vesely and Assine (2014) challenged such interpretation, arguing that the lack of lateral continuity, the presence of marginal berms, the absence of subglacial deposits and the fact that orientation of striations is not as consistent as the truly subglacial features found in the area would indicate that the surfaces were eroded by keels of free-floating ice masses on subaqueous fan and/or delta sediments, and that multiple ice advances are not needed to explain the vertical repetition of striated surfaces.

\section{Methods and key definitions}

This research is based on the examination of outcrops in the eastern border of the Paraná Basin in southeastern Paraná state, southern Brazil (Fig. 3). About 20 outcrops of the lower Itararé Group and its Devonian substrate, in the form of road cuts, quarries and natural exposures, were analyzed through the assembly of vertical logs and two dimensional sketches. The stratigraphic framework was delineated by the correlation of ten vertical logs and the elaboration of a structural crosssection (Fig. 3). Biostratigraphical control was obtained by pollen and spore species retrieved from localities 7 and 6 (Fig. 3), as previously described by Kipper (2014) and considering the biozones presented by Souza $(2000,2006)$. The applied definition of diamictite followed that of Flint et al. (1960), in which a diamictite is a matrix-supported, nonsorted admixture of mud, sand and gravel. Paleocurrent data were taken from cross-stratification and climbing ripples observed in sandstones. Surfaces exhibiting linear features generated by glacial erosion were described and the orientation of negative (striations and grooves) and positive (ridges) structures was measured. The term striated/ grooved pavement is used here to define bedrock surfaces abraded by ice, being essentially subglacial features. Soft-sediment striated/ grooved surfaces (e.g., Woodworth-Lynas and Dowdeswell, 1994), on the other hand, are surfaces generated by ice erosion on non-lithified beds and are thus penecontemporaneous features. These can be the product of subglacial erosion caused by the advance of a glacier on soft-sediments, where it appears normally as flat and laterally extensive surfaces and commonly associated with other landforms of subglacial origin (e.g., flutes and drumlins), or result from scouring of floating ice on subaqueous sediments (ice-keel scour marks), forming laterally discontinuous striated/grooved surfaces bordered by berms (WoodworthLynas and Dowdeswell, 1994). 


\section{Stratigraphy}

In the study area the Itararé Group rests by means of an angular unconformity on the pre-glacial substrate, which is composed of increasingly older units to the southeast (Fig. 3A). As a result, Itararé deposits sit on different rock types, which include, from the oldest to the youngest, Precambrian crystalline rocks, Devonian sandstones of the Furnas Formation and Devonian shale and siltstones of the Ponta Grossa Formation.

The studied succession is about $90 \mathrm{~m}$ thick and corresponds to the lowermost interval of the Itarare Group, which is equivalent to the lowermost deglaciation sequence of Vesely and Assine (2006). An age no younger than the Moscovian (312-306 Ma) for these basal glacial deposits is supported by palynomorphs found in the first shale horizon situated about $70 \mathrm{~m}$ above the unit's base (Kipper, 2014). The upper limit of the succession is a widespread, gently angular unconformity capped by reddish, postglacial sandstones (Vila Velha sandstone). Below this unconformity, three stacked lithostratigraphic units were recognized, named 1 to 3, which, in spite of lateral thickness variations, can be traced along most of the studied area (Figs. 3, 4). Facies analysis resulted in the definition of four genetic facies associations. Units 2 and 3 comprise one association each, but unit 1 can be further subdivided into two associations (units 1-A, 1-B). The subdivision of unit 1 in subunits was because they have a close genetic relationship in the inferred depositional environment and because their distinction is not always possible from available outcrop data.

\subsection{Unit 1-A: Subglacial to ice-marginal deposits}

\subsubsection{Description}

Unit 1 is irregularly distributed across the study area and has a thickness ranging from 0 to $28 \mathrm{~m}$. Regardless of local thickness changes the unit generally thins towards the north, being absent in the Vila Velha region (Fig. 4). Unit 1-A is an approximately $10 \mathrm{~m}$ thick diamictite succession resting directly on the Devonian substrate. Diamictites are typically unstratified and composed of angular to rounded clasts of variable lithologies (granite, schist, quartzite and sandstone) immersed in a sandy-silty matrix (Fig. 5A). They may exhibit millimeter-spaced, low angle shear planes or foliation dipping to the south (Fig. 5B).

Where diamictites rest on the Furnas sandstones, glacially striated pavements are common. These pavements contain straight and parallel striations, grooves and ridges, oriented northward, with relief ranging from few millimeters to few tens of centimeters and a semicircular cross sectional profile (Fig. 5C). Although not observed in the present study because of the deterioration of the exposure, Bigarella et al. (1967) described crescentic fractures associated with one of these striated pavements (Witmarsum; Fig. 3) that would indicate ice flow towards the north-northwest. In the northern sector of the study area the diamictites rest on grayish shale of the Ponta Grossa Formation. Here, the contact between the diamictite and the shale is marked by a $50 \mathrm{~cm}$ thick deformed zone composed of plastically deformed, irregular fragments of shale and dark argillaceous bands partially mixed with a poorly sorted sandy matrix (Fig. 5D). As a result, the first few meters of the diamictite have a characteristic pale gray color due to the incorporation and mixing of mud from the underlying Devonian shale.

In the Purunã region (locality 2 in Fig. 3) a laterally extensive grooved surface lies on top of the diamictite succession (Fig. 5E). The surface is flat and contains irregularly spaced grooves and ridges up to $50 \mathrm{~cm}$ wide, $20 \mathrm{~cm}$ deep, and oriented $012^{\circ}$. Grooves have a "U-shaped" crosssectional profile whereas ridges are commonly flat-topped. Some ridges are placed at the lee side of large clasts (Fig. 5F) resembling small subglacial flutes (van der Meer, 1997; Trosdtorf et al., 2005a; Kjaer et al., 2008).

\subsubsection{Interpretation}

The fact the diamictites of unit 1-A are cut by a subglacial grooved/ fluted surface and rest above striated pavements carved on bedrock suggests that these sediments were emplaced directly by ice, representing thus basal tillites. In addition, the non-stratified character, the absence of expressive mudstone and/or sandstone interbeds and the presence of foliation are characteristics commonly found in glacial till (Bennett and Glasser, 2009). Foliation is a common product of subglacial glaciotectonics and form as a result of shearing impinged by the ice as it moves on a deforming bed made of unconsolidated sediments (Hart and Roberts, 1994; van der Meer et al., 2003; Roberts and Hart, 2005; Evans et al., 2006).

Features observed at the Devonian substrate indicate that the bed on which diamictites of unit 1-A were deposited was eroded by moving ice in at least two different forms due to variable rheology. The striated/ grooved pavements on the highly cemented Furnas sandstones were generated by abrasion of clasts transported at the ice sole, indicating the advance of a glacier on rigid bedrock (Boulton, 1979; Bennett and Glasser, 2009). On the other hand, the deformed zone at the contact between the diamictites and the underlying Ponta Grossa shale was produced by subglacial deformation of a weakly consolidated, erodible bed composed of argillaceous sedimentary rock (e.g., Isbell, 2010). The presence of irregular shale fragments (Fig. 5D) may indicate that the Devonian shale were originally fractured, facilitating the removal of blocks via plucking (Rattas and Kalm, 2004).

The grooved/fluted surface on top of the diamictite is an example of the intraformational, soft-sediment glacial surfaces widely reported in Gondwana (e.g., Visser, 1990; Von Brunn, 1996; Gesicki et al., 2002). These structures record ice erosion and/or deformation of unlithified beds and may form in three different situations: 1) as subglacial lineations, 2) as grounding line furrows, or 3 ) as ice-keel scour marks. The large dimensions and flat character of the surface, as well as the absence of marginal berms, mismatch with the ice-keel scour marks observed in modern and Quaternary enviroments (e.g., Woodworth-Lynas and Dowdeswell, 1994). The presence of flutes in the form of sediment ridges at the lee-side of obstacles, on the other hand, is strongly indicative of subglacial environment because flutes are not reported in association with ice-keel marks or grounding line furrows (O'Brien and Christie-Blick, 1992; Woodworth-Lynas and Dowdeswell, 1994). The poorly-sorted character of unit 1-A sediment is similar to what is observed in modern fluted terrains (e.g., Kjaer et al., 2008), strengthening the interpretation of a subglacial origin for this surface. According to Hart and Smith (1997), the formation of flutes can be explained by two mechanisms: 1) passive deposition from the debris-rich basal ice in subglacial cavities, and 2) deformation of a subglacial deforming layer as the ice flows around an obstacle. Observations of modern environments where flutes are associated with debris-free basal ice presume that the second explanation is more likely (Boulton, 1976; Hart and Smith, 1997; van der Meer, 1997).

In synthesis, deposition of unit 1-A can be explained by considering a single, major event of ice advance in which deposition, erosion and deformation occurred as a continuum of processes in the subglacial environment (Hart and Roberts, 1994). At high effective pressures and associated rigid bed conditions deposition took place primarily by lodgement and, depending on rheology, the substrate was affected by abrasion or deformation. Continuous accumulation of sediment at the glacier/bed interface gave rise to a subglacial, deforming bed in which stress transferred by the overriding glacier caused shearing and the development of foliation. The role of subglacial glaciotectonic deformation is also evidenced by the presence of flutes on the top surface of the diamictites, which record flow of the deforming bed into lee side cavities (Hart and Smith, 1997). Grooves and striations also occur in the same surface, indicating plowing of the diamictite due to sliding of the ice onto the deforming bed.

\subsection{Unit 1-B: Glaciotectonized, ice-contact lake deposits}

\subsubsection{Description}

Unit 1-B is restricted to the southeastern sector of the studied area (localities 1, 2 and 3 in Fig. 3) and consists of a very heterogeneous 

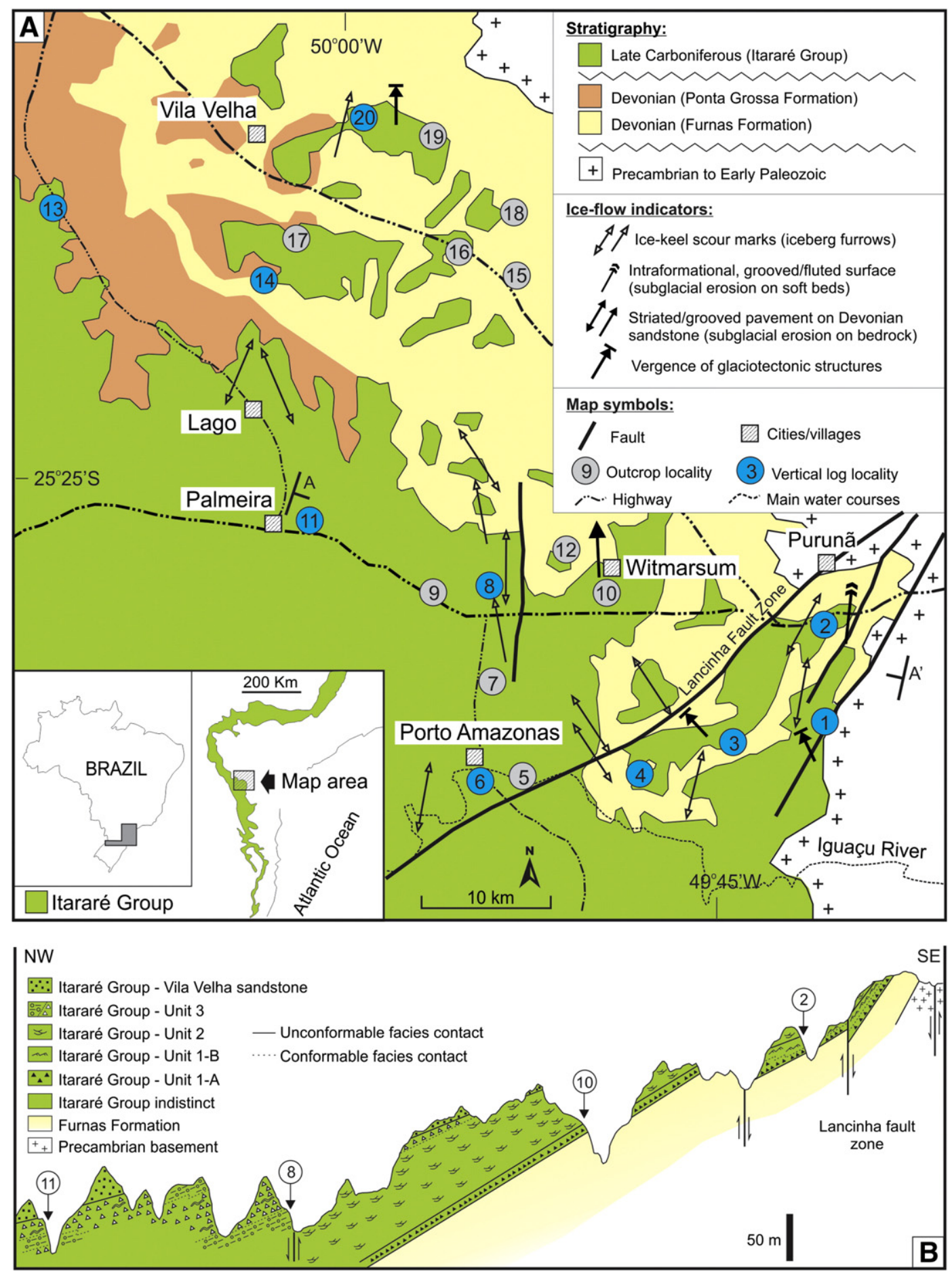

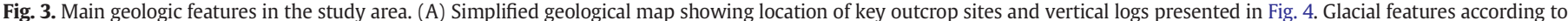

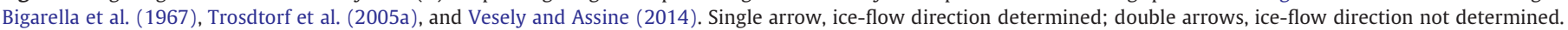

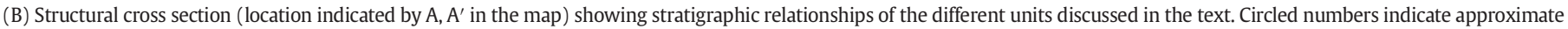
location of some outcrop localities shown in A.

interval resting abruptly on diamictites of unit 1-A. The top boundary is an erosive surface underlying coarse grained sandstones or conglomerates of unit 2. Facies type and the overall stacking pattern of unit 1-B vary from place to place, indicating significant lateral changes in depositional processes. In general, a reduction in grain size is observed from south to north (Fig. 4), a trend roughly parallel to the northward paleoice flow deduced from the underlying glacial surfaces. This observation points to a proximal, coarser domain to the south (localities 1 and 3;
Fig. 6A, B and C) and a distal, finer domain to the north (locality 2; Fig. 6D and E).

In the proximal domain unit 1-B is composed of a lower sand-rich interval, about $15 \mathrm{~m}$ thick in locality 1 and $10 \mathrm{~m}$ thick in locality 3 (Fig. 4). This includes cross-stratified sandstones, stratified, sandy-muddy diamictite and lenses of clast supported, massive conglomerate. Sandstone beds have a gently sigmoidal geometry defining few metershigh clinoforms dipping north. Stratification in diamictites is defined 


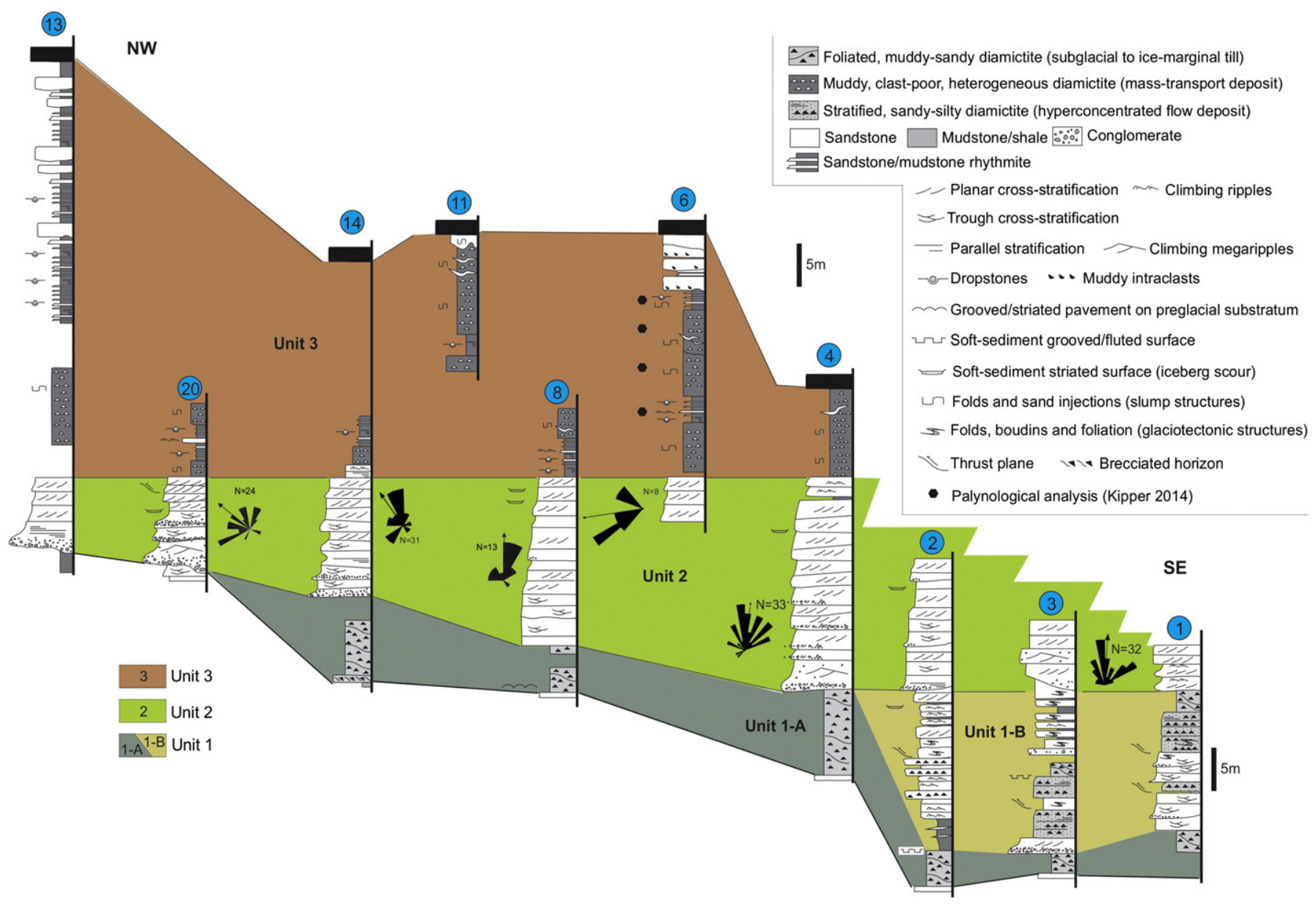

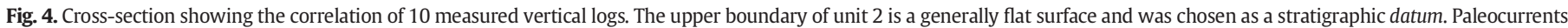
were taken from trough and planar cross-stratification and climbing ripples. See Fig. 3 for location.

by long axis orientation of pebbles, grain size changes as well as a distinct fabric clearly associated with subsequent shearing (Fig. 6A and B). Dropstone-like structures may be present in these sheared diamictites (Fig. 6A). Bedsets in this lower sand-rich interval are commonly bounded by low-angle, few decimeters thick zones of intense shearing (Fig. 7A, B and C). These shear zones dip towards the south-southeast, are commonly associated with decollement surfaces and have an internal anastomosed pattern, sometimes with small-scale thrusts (Fig. 7A) and folds (Fig. 7D) which indicate transport towards the north-northwest. Homogenized mudstones may occur associated with the shear zones, indicating higher strain rates (Fig. 7A and B). Bed sets above and below shear zones are commonly folded and/or tilted, increasing the angle of clinoform foresets in sandstones (Fig. 7C). The lower sand-rich interval is truncated on top by a planar surface which exhibit, in locality 3 (Fig. 4), poorly exposed glacial grooves and ridges. This surface occurs also in locality 1 indicating a lateral continuity of about $6 \mathrm{~km}$ in the strike direction. Above this surface there is a body of muddy-sandy, unstratified, foliated diamictite very similar to those present in unit 1-A. This diamictite body is, in turn, overlain by a succession of rippled, often deformed, fine to medium grained sandstones interbedded with massive mudstones (locality 3 ), or is truncated on top by the basal boundary of unit 2 (locality 1 ).

In the distal domain (locality 2 in Figs. 3, 4) unit 1-B is relatively finer grained, lacks the lower sand-rich interval observed in the proximal domain and exhibits a clear coarsening upward stacking pattern (Fig. 4). The base is composed of massive mudstones with sigmoidal sandstone bodies that pass upward to a succession composed of meter-thick beds of rippled and cross-laminated sandstones (Fig. 6D and E) and sandymuddy, stratified diamictites. Soft-sediment deformation occurs more locally and consists of folds affecting fine-grained, rippled sandstone. The base of the main deformed interval in locality 2 is marked by a thrust plane dipping gently to the south. The diamictite body and associated grooved surface observed in unit 1-B in localities 1 and 3 are absent in this more distal domain.

The uppermost part of unit 1-B in locality 2 shows soft-sediment striated surfaces carved in rippled sandstones. At least four striated surfaces occur on the same bed boundary, with all striations oriented NNE. The largest surface is about $1 \mathrm{~m}$ wide and shows a well-developed trough-like, flat-bottomed transversal profile bordered in its western side by a prominent marginal berm (Fig. 7E). Climbing ripples (Fig. 6E) occur laterally to marginal berms in the same bed, whose paleocurrent is roughly parallel to the grooves. Kinematic evidence for ice flow was not identified.

\subsubsection{Interpretation}

Facies observed in the lower sand-rich interval of unit 1-B (proximal domain) do not support deposition directly by the ice. Instead, the presence of grading and clast elongation in the diamictites and their intimate association with cross-stratified and climbing rippled sandstones strongly suggest deposition from density flows (e.g., Eyles et al., 1985). The high amount of sand and the presence of crude stratification in these diamictites point to hyperconcentrated to concentrated flows, in which particles are supported by the combination of matrix strength, dispersive pressure and fluid turbulence (Mulder and Alexander, 2001). Cross-stratified sandstones record dune migration under bed-load dominated currents and climbing rippled sandstones indicate rapid deposition by traction plus fallout. The association between dense flows and hydrodynamic currents indicates extreme fluctuations in flow 

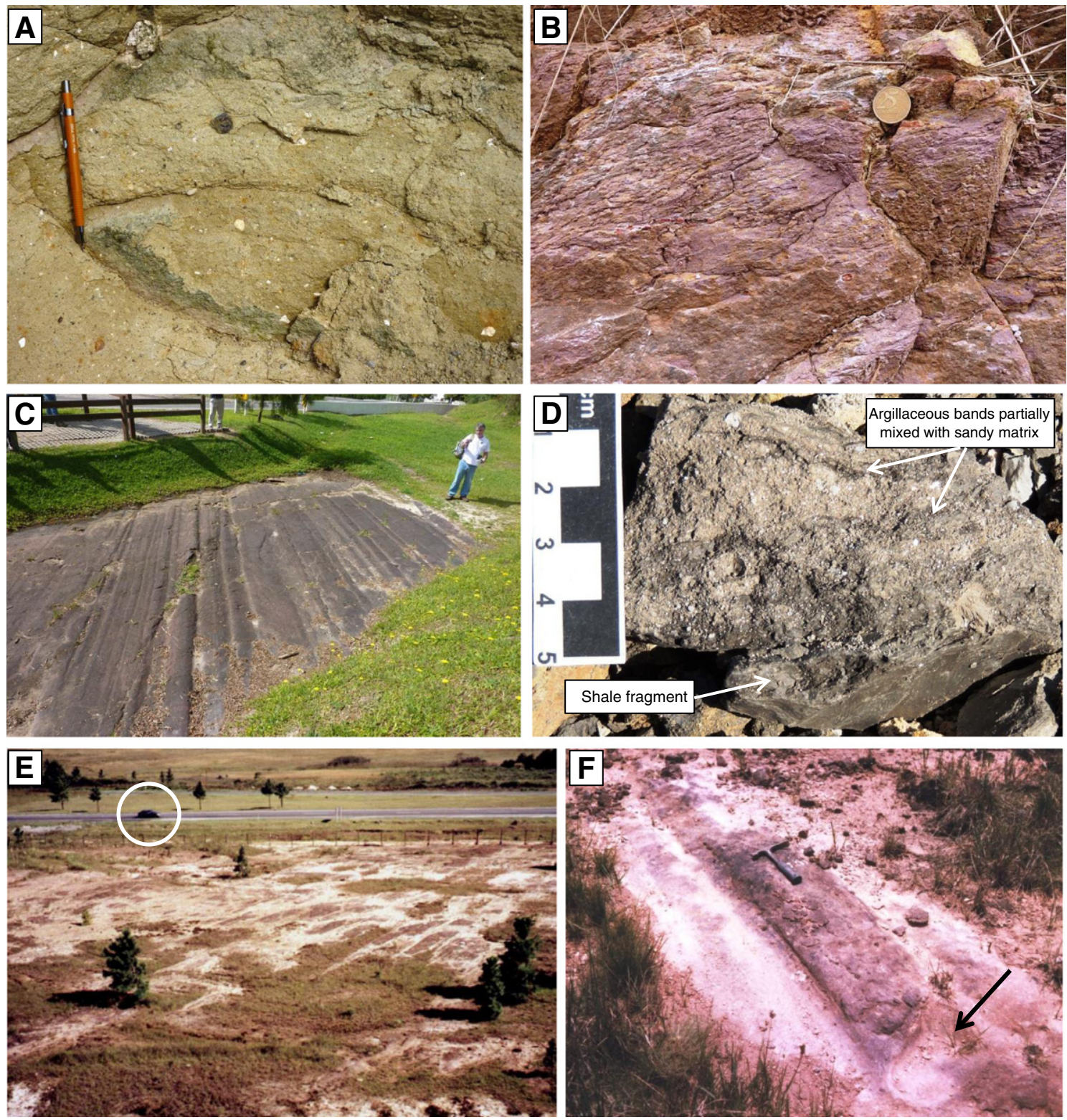

Fig. 5. Field photos of Unit 1-A. (A) Non-stratified, sandy-silty diamictite. (B) Non-stratified, clast-poor diamictite displaying glaciotectonic foliation which indicates ice flow to the right (coin as scale). (C) Striated and grooved pavement onto Devonian sandstones of the Furnas Formation at Witmarsum; ice flow towards the bottom of the image. (D) Hand specimen of a sandy-silty diamictite near the contact between unit 1-A and the Ponta Grossa Formation showing a shale fragment and argillaceous bands (dark gray) partially mixed with poorly sorted sand. Scale bar in centimeters. (E) Extensive grooved/fluted surface on foliated diamictite at Purunã (ice flow towards the upper right; circled vehicle on the background as scale). (F) Detail of a small flute from the same surface shown in E with arrow indicating the hollow left by the boulder that served as obstacle for sediment to accumulate; ice flow towards the upper left.

power with time, a characteristic commonly observed in ice-marginal environments where sediment supply is controlled by meltwater efflux jets that emanate from englacial or subglacial tunnels, enter the water body and give rise to grounding-line fans and/or ice-contact deltas (Powell, 1990; Russell and Arnott, 2003; Hornung et al., 2007).

The muddy-sandy, foliated diamictite sitting on an intraformational grooved surface is similar to the diamictites observed in unit 1 and can be interpreted as a subglacial till deposit. This indicates that the surface overlying the lower sand-rich succession was formed by subglacial erosion onto soft sediments. The deformation structures observed in unit 1-B are essentially compressive, including thrust faults and folds, and are located both above and below the subglacial till unit. Considering these characteristics and the fact that orientation of faults and fold axis are consistent with a regional ice flow towards the north as indicated by subglacial lineations, this deformation can be attributed to ice push onto soft sediments, being thus a product of proglacial glaciotectonics (Hart and Boulton, 1991; van der Wateren, 1994).
The soft-sediment striated surface observed in the uppermost part of unit 1-B is interpreted as an iceberg scour (Vesely and Assine, 2014). Supporting this interpretation is the presence of non-striated marginal berms, the absence of subglacial deposits in this specific stratigraphic level and the lateral association with subaquatic facies such as climbing rippled sandstones. These characteristics are typical of furrows formed underwater by ice-keel scouring in both modern and Pleistocene marine and lacustrine environments (Woodworth-Lynas and Dowdeswell, 1994; Eyles et al., 2005).

In synthesis, the facies characteristics of unit 1-B, the presence of clinoforms and ice-keel scours, and the occurrence of coarseningupward stacking patterns conformably above a muddy interval in the more distal domain (locality 2), indicate deposition within a water body. The restricted distribution of unit 1-B in the southeastern sector of the study area points to a localized water body, probably a lake, bounded in the south by the ice margin. The observations that unit 1-B thins and disappears to the northwest and lies above glaciogenic 

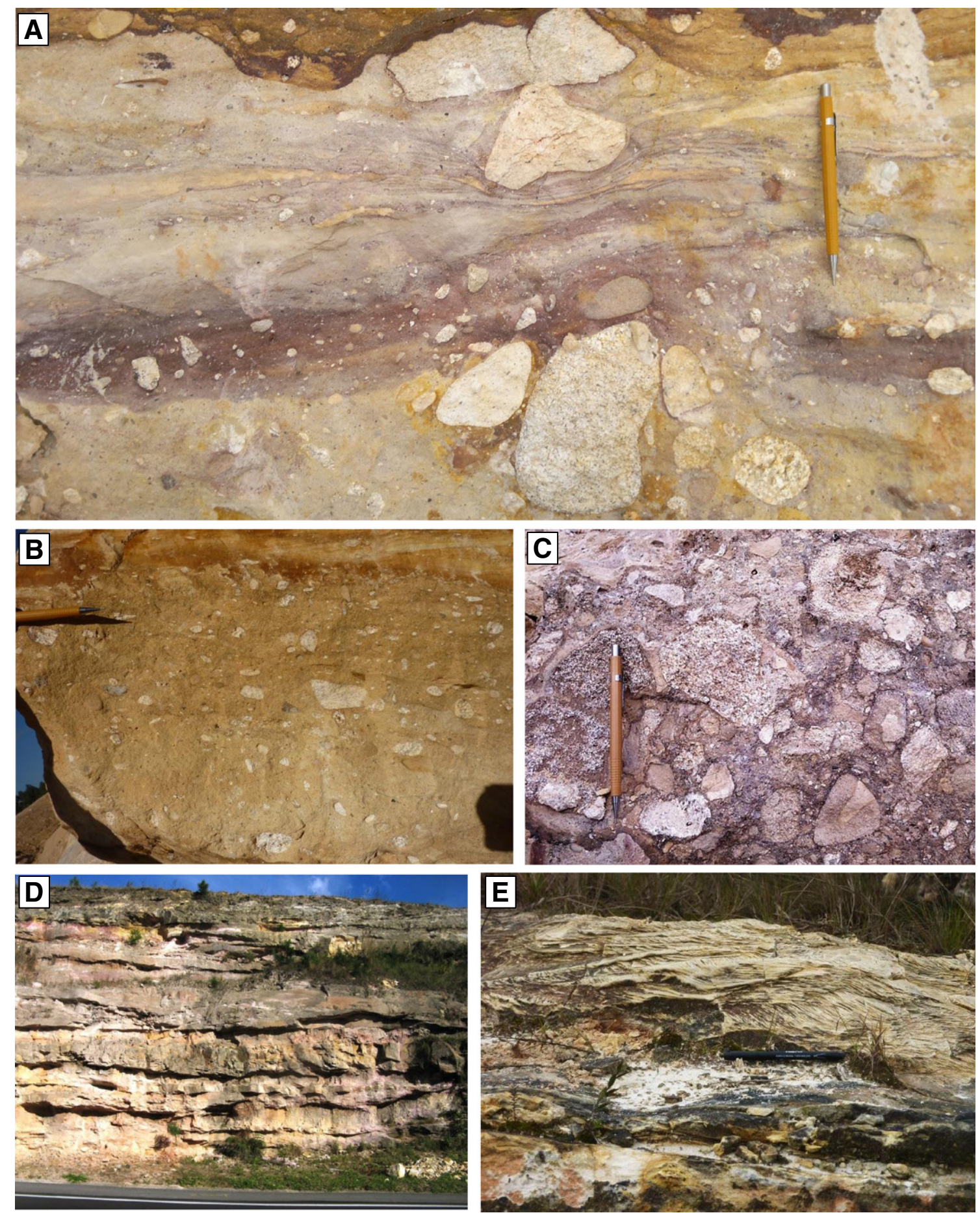

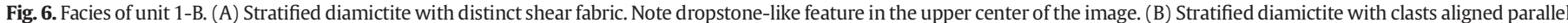

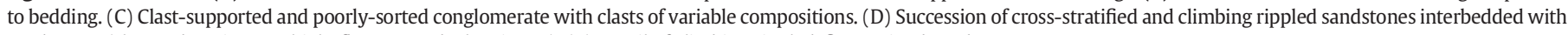
mudstones (the road cut is $10 \mathrm{~m}$ high; flow towards the viewer). (E) Detail of climbing rippled, fine grained sandstone.

diamictites of unit 1-A (Fig. 4) suggest onlap of the lake-fill deposits onto a topographic high composed of glacial sediment (mainly icemarginal till). A probable scenario is thus of a lake bordered by a moraine ridge in its distal portion, forming a moraine-dammed, icecontact lake (e.g., van der Wateren, 1994; Bennett and Glasser, 2009). Re-advances of the ice margin caused deformation of the lake sediment by pushing and, occasionally, lead to deposition of subglacial till onto it when the ice overrode the lacustrine sediments (e.g., Boulton, 1986).

\subsection{Unit 2: Proglacial fan and delta deposits}

\subsubsection{Description}

This unit is up to $25 \mathrm{~m}$ thick and has a characteristic fining-upward stacking pattern (Fig. 4). Its lower boundary is unconformable with unit 1 (Fig. 8A) or, more locally, directly with the Devonian substrate. Unit 2 is essentially composed of very coarse to fine, moderately to poorly sorted, white colored sandstones and subordinate conglomerates. 

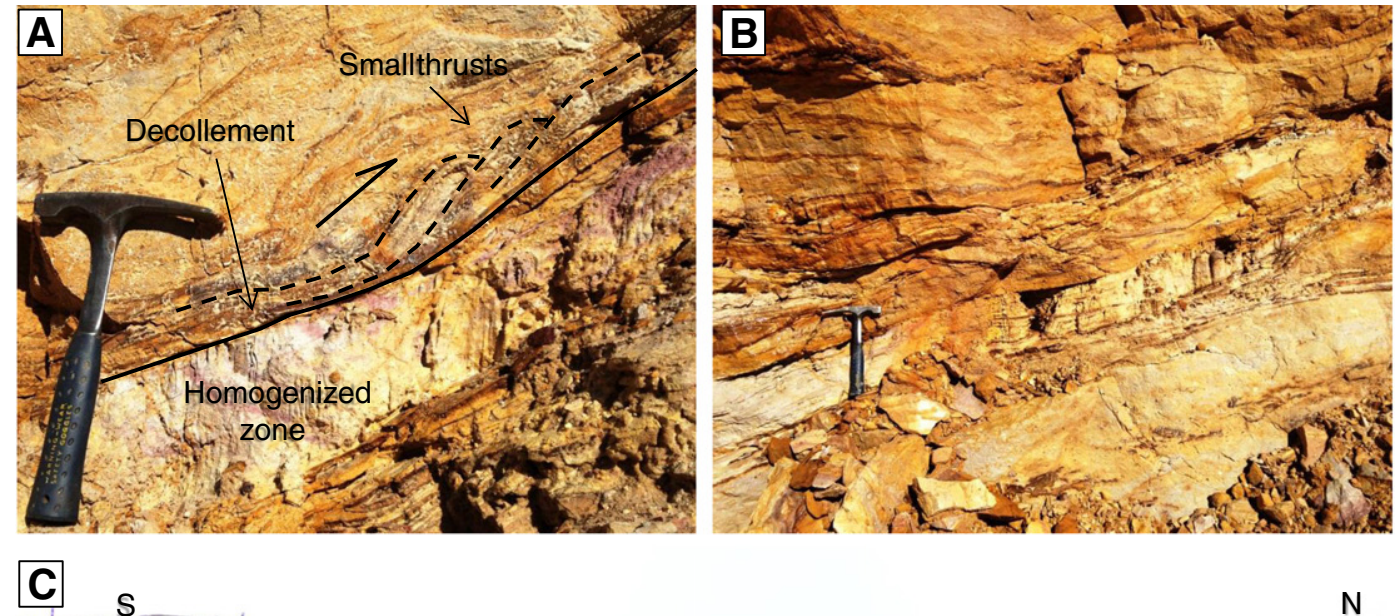

$\mathrm{S}$
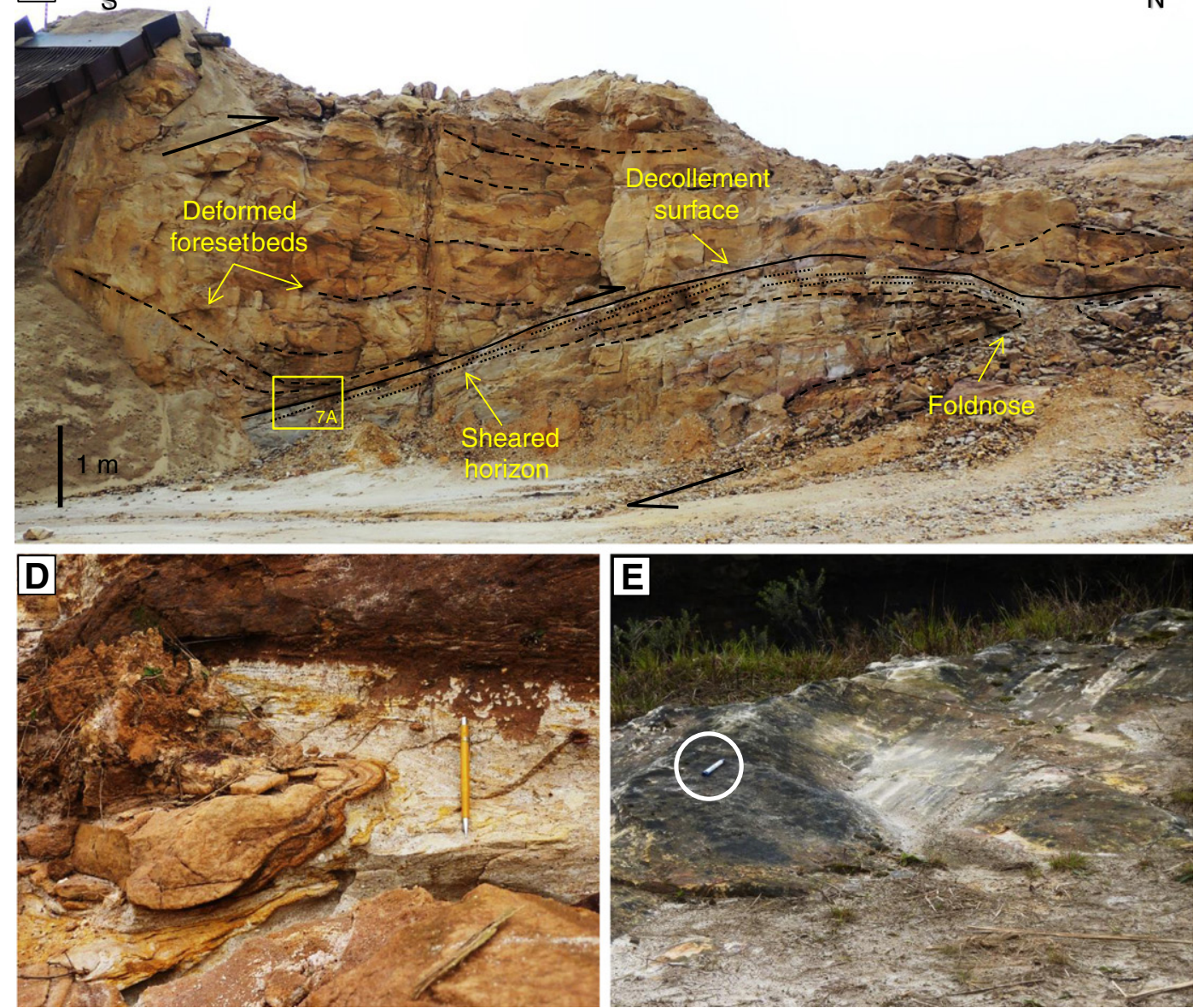

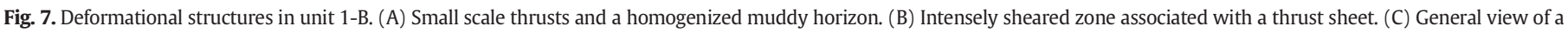

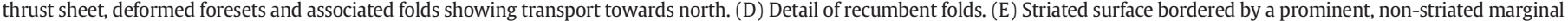
berm (circled pen as scale).

Different facies are observed, the most common being through or planar cross-stratified sandstones arranged in 10 to $150 \mathrm{~cm}$ thick tabular to lenticular beds (Fig. 8C). Conglomerates and very coarse sandstones, often with oversized clasts, massive or disposed in large (up to $2 \mathrm{~m}$ thick) sets of cross-stratification occur in the lower part of unit 2 (Fig. 8B). They can be associated with pebbly sandstones with climbing megaripples, some reaching several meters in wavelength (Fig. 9E).

In laterally extensive exposures it is possible to observe that sandstone beds are organized as downstream accretion macroforms (Fig. 8F), often limited by trough-like bounding surfaces (Fig. 8A). Within some of these macroforms cross-stratified sandstones pass downflow to climbing rippled, fine-grained sandstones (Fig. 8D), and define gently dipping clinoforms. Paleocurrents measured from the cross-stratified sandstones indicate flow direction ranging from WSW to NNE (Fig. 4).

Soft-sediment striated surfaces (Fig. 9) take place at different stratigraphic levels within unit 2 on the bedding planes of cross-stratified sandstones (Vesely and Assine, 2014). Surfaces are laterally discontinuous and have straight or curvilinear parallel striations, grooves and ridges, as well as isolated grooves and small-scale structures indicative of slumping, sediment pushing, and folding. Like the one observed in the upper part of unit 1-B, some surfaces are trough-like with concave or flat-bottomed cross-sectional profiles and are bordered by nonstriated marginal berms. Orientation of linear features range from $324^{\circ}$ to $025^{\circ}$ azimuth and kinematic evidence such as lodged pebbles, nailhead 

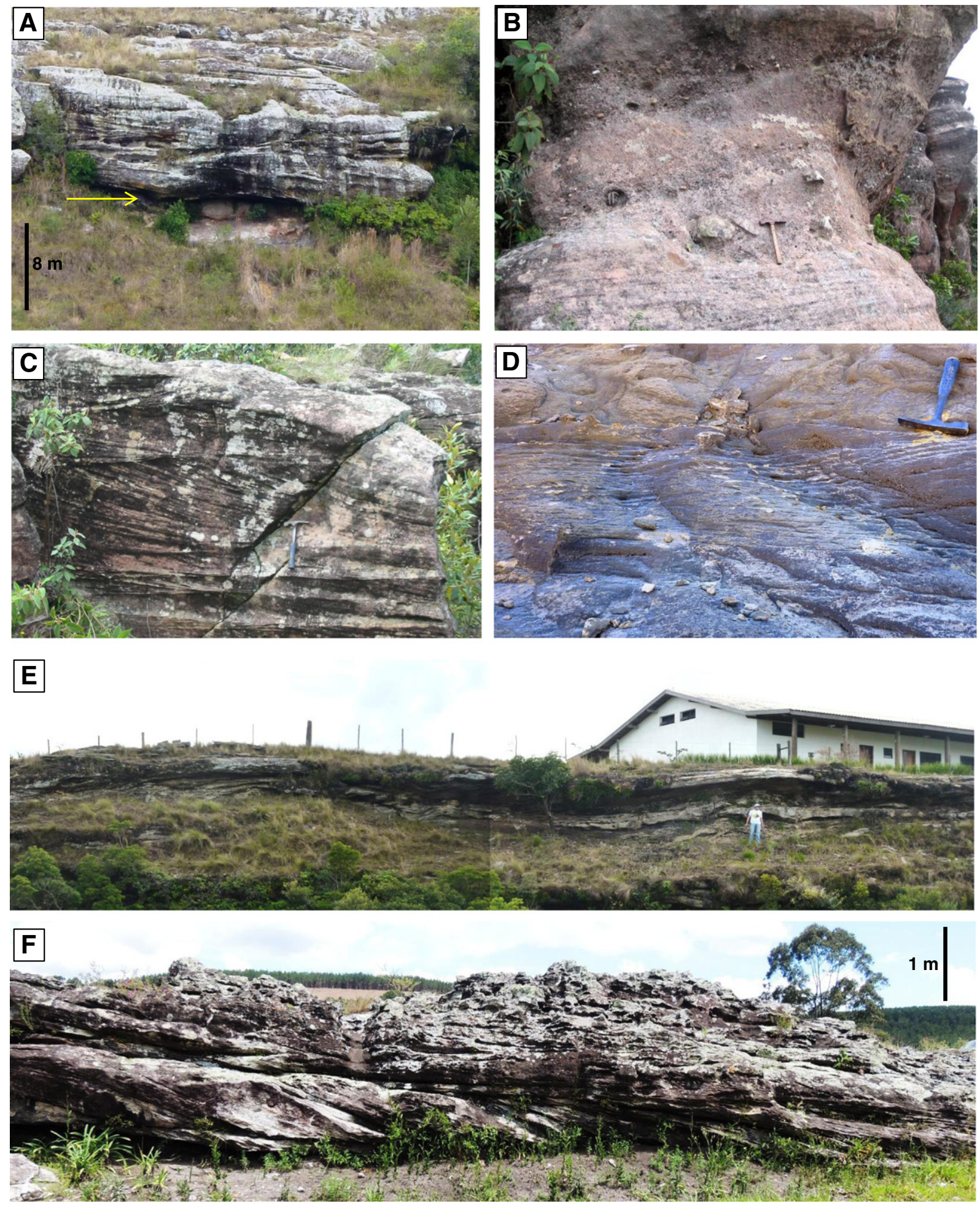

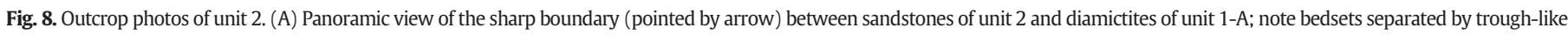

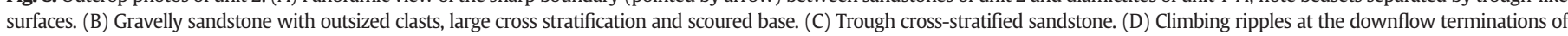
cross-stratified units. (E) Mega ripples in pebbly sandstones (flow towards the right). (F) Medium-grained, planar cross-stratified sandstone showing downstream accretion surfaces.

furrows (Fig. 9C) and asymmetrical cavities indicate ice flow towards the north.

In the north sector of the study area (locality 20), sandstone beds of the upper part of unit 2 are affected by a prominent thrust fault dipping to the south-southeast (Fig. 10). Beds of the overlying unit 3, on the other hand, are not deformed and onlap onto the thrust front. This structure indicates transport towards the north-northwest, which is roughly parallel to subglacial lineations found in lower stratigraphic levels.

\subsubsection{Interpretation}

Sandstones with cross stratification are the product of bedloaddominated, unidirectional currents and the presence of downstream accretion macroforms suggests flows in low sinuosity systems (e.g., Miall, 

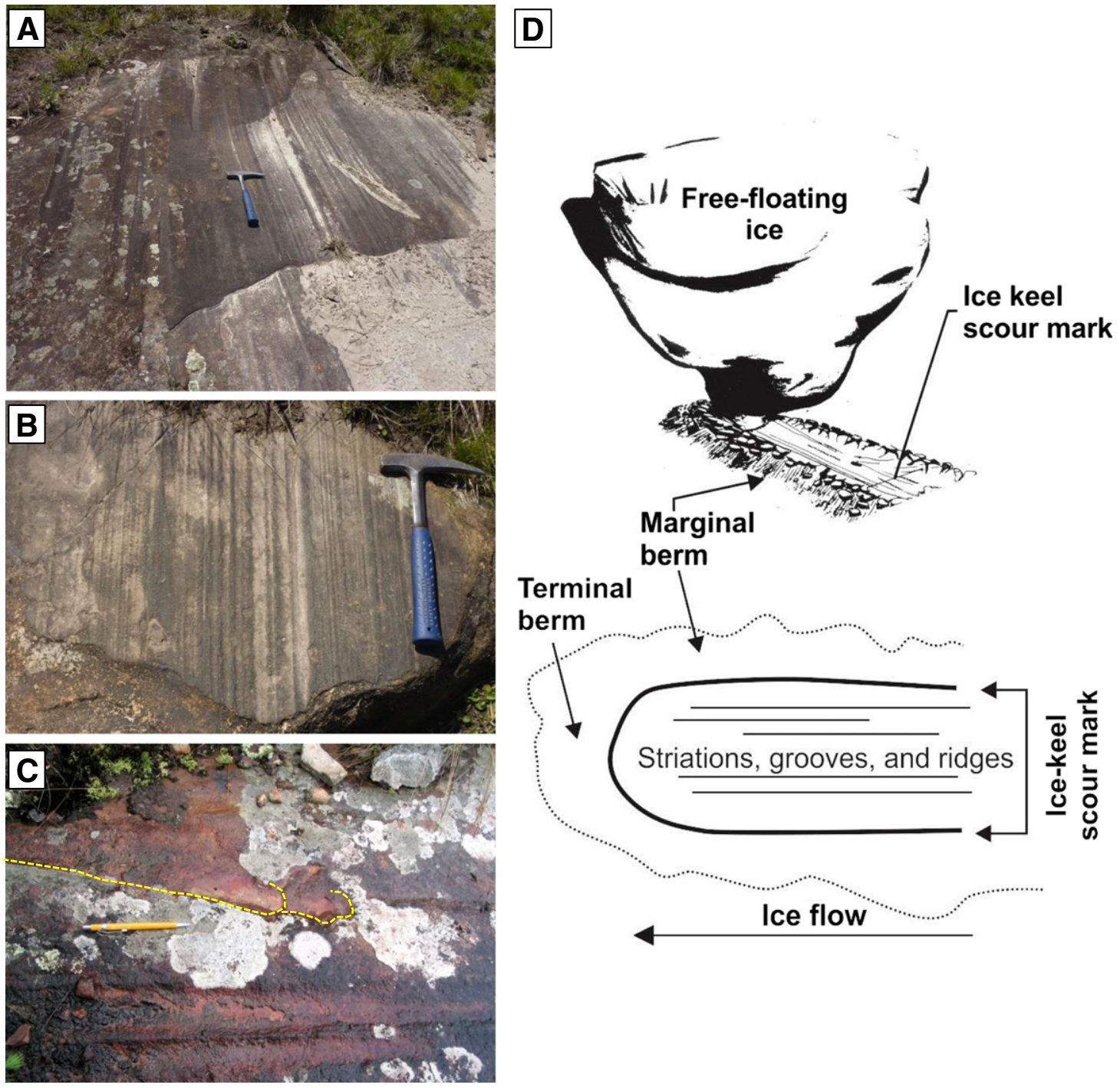

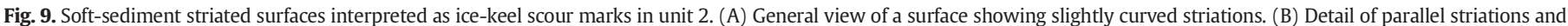

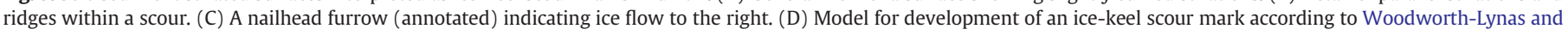
Dowdeswell (1994) and Eyles et al. (2005).

1985). Gently dipping clinoforms with climbing ripples form as a result of flow expansion and loss of transport competence, conditions usually associated with channel-mouth bars (e.g. Hornung et al., 2007). The massive to crudely stratified conglomerates and pebbly sandstones observed in the lower part of the unit were generated by more concentrated flows during periods of higher discharge. The m-thick cross stratification in these coarse-grained facies results from migration of large gravelly bedforms, which requires highly energetic currents. Even more catastrophic flows are invoked to explain the deposition of coarse-grained, climbing megaripples (Mutti et al., 1996; Ghienne et al., 2010), because the current had to be strong enough to carry very coarse sand and pebbles in suspension allowing the preservation of stoss-side strata. This can be explained by considering sediment-laden stream flows (e.g. Mutti et al., 1996) in which the high concentration of particles in the current can contribute to support even gravel in suspension.

The soft-sediment striated surfaces found in between sandstone beds have characteristics that allow their interpretation as ice-keel scour marks developed by drifting ice (Fig. 9D). As discussed in a previous paper (Vesely and Assine, 2014), these include: 1) the presence of linear grooves and ridges, marginal berms, lodged pebbles, and smallscale slump structures like those observed in modern and Pleistocene ice-keel scour marks (e.g., Dionne, 1969; Woodworth-Lynas and
Dowdeswell, 1994; Eyles et al., 2005); 2) the presence of narrow ( $5 \mathrm{~cm}$ wide), isolated grooves, more likely to form by ice keels than beneath grounded glaciers; 3 ) the close genetic relationship of striated surfaces with proglacial deposits and not basal tills; and 4) orientation of linear features commonly deviated from the regional glacial flow deduced from truly subglacial lineations (see Fig. 3).

The depositional characteristics described above are consistent with subaqueous grounding-line fans described in the Pleistocene (e.g., Cheel and Rust, 1986; Powell, 1990; van der Wateren, 1994; Lønne, 1995; Hornung et al., 2007). They consist of fan-shaped or coalescing, coarse-grained depositional systems that form in marine or lacustrine environments close to the exit of subglacial or englacial tunnels. The finning upward character results from the backstepping of the fan system due to ice retreat (Cheel and Rust, 1986), meaning that lower deposits were deposited closer to the ice margin. In these proglacial settings high frequency alternation of subaerial and subaqueous sedimentation may occur because during periods of high sedimentation rates and stable ice margin, subaqueous fans may aggrade rapidly to the water level, forming subaerial deltaic topsets (Powell, 1990). In these settings, distinction between subaerial and subaqueous facies may be difficult because bedload-dominated currents can operate either in the subaerial topset (e.g. Lønne, 1995) as subaqueously due to jets that emanate 

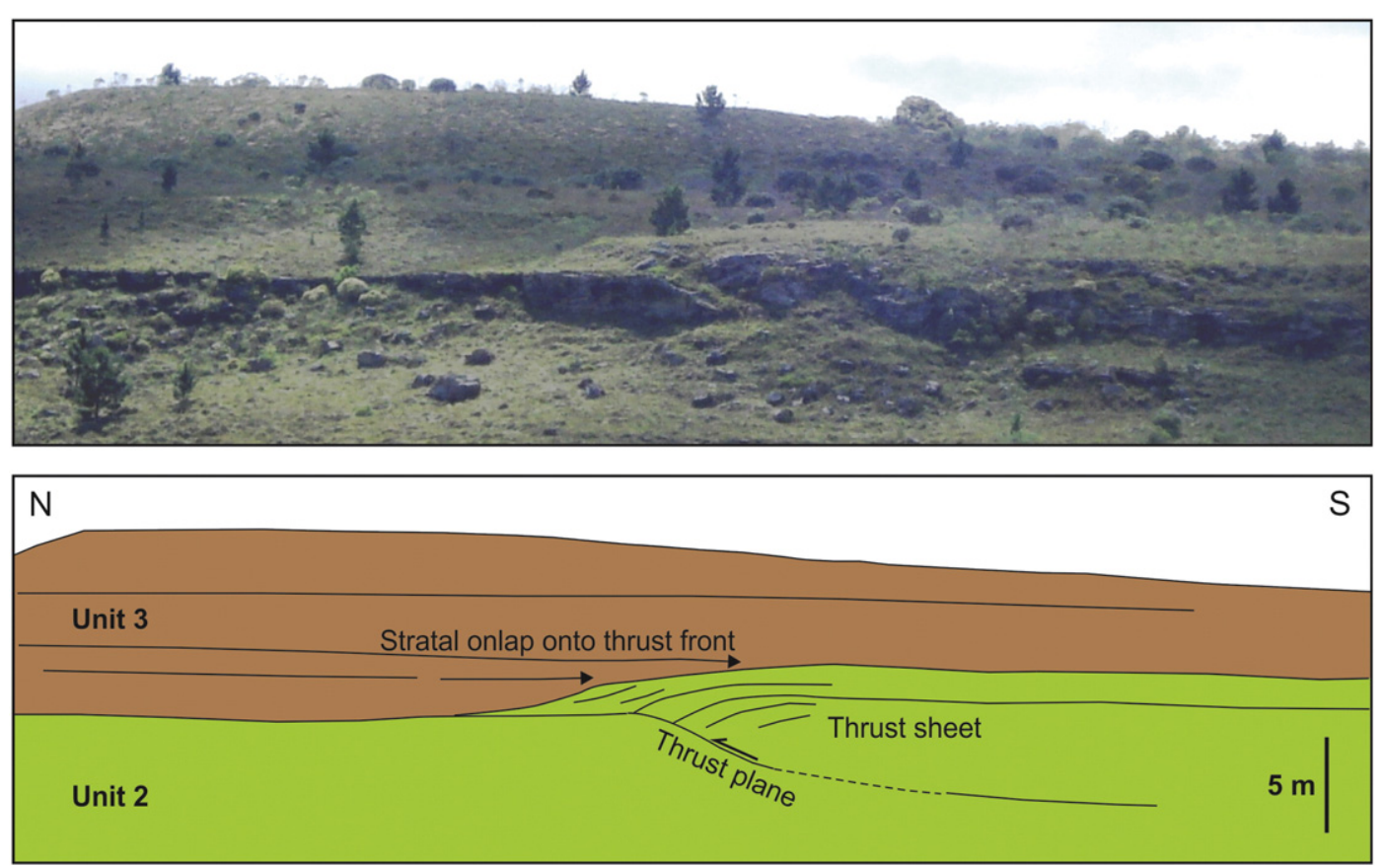

Fig. 10. Thrust fault affecting sandstone beds of the upper part of unit 2 . Note that beds of unit 3 onlap the thrust front and are not affected by deformation.

from the subglacial tunnels (e.g. Hornung et al., 2007). However, the presence of iceberg scours in different stratigraphic levels suggests that sedimentation took place mainly underwater in the form of grounding-line fans and that subaerial (deltaic) conditions were subordinate. The thrust-fault observed in locality 20 is interpreted as a glaciotectonic feature and was formed as a result of ice push onto the proglacial sands during a re-advance of the ice margin.

\subsection{Unit 3: Glacially-influenced submarine slope deposits}

\subsubsection{Description}

Unit 3 rests conformably on unit 2 and is truncated on top by the subaerial unconformity that is the lower boundary of the Vila Velha sandstone. The unit is up to $50 \mathrm{~m}$ thick and comprises an association of muddy-matrix, clast-poor diamictites, thin-bedded rhythmites, laminated mudstones and structureless sandstones (Fig. 11). Diamictites occur as 3 to $10 \mathrm{~m}$ thick units that may consist of a single body or comprise multiple diamictite bodies bounded by irregular scours. These diamictites are distinct from those of the underlying units because of the muddier matrix, fewer clasts $(<5 \%)$, the occurrence of subvertical sandstone dykes, and the presence of large (several meters), plastically deformed blocks of sandstone and shale (Fig. 11A and B). The matrix can be homogeneous or heterogeneous, the latter showing discontinuous remnants of stratification and/or deformed sand streaks. Clasts within diamictites are subrounded to angular, frequently faceted and striated and range from granules to boulders of crystalline rocks (granite, schist, and quartzite).

Rhythmites consist of sharply based, centimeter-thick, graded beds composed of very fine sandstones passing to mudstones, with common sole marks, frequent current ripples and rare convolute bedding. Dropstones are common and consist of granules to cobbles of crystalline rocks such as granite and quartzite (Fig. 11C). These rhythmites grade to laminated mudstones forming cyclic packages with thinning/fining and thickening/coarsening upward trends (Fig. 4). In localities 6 and 13 (Figs. 3,4 ) the rhythmites are associated with tabular to lenticular beds of fine- to coarse-grained, structureless sandstones. The beds are 50 to $150 \mathrm{~cm}$ thick, do not display any clear grain-size trend, and may form amalgamated bedsets or intercalate with rhythmite/mudstone horizons (Fig. 11D and E). Rip-up mud clasts, load casts and small-scale softsediment deformational structures are common in these sandstones.
Previous studies in the Vila Velha area (França et al., 1996) identified specimens of Tasmanites and Botryoccocus in an interval equivalent to unit 3, which would indicate brackish waters and thus marine influence in the depositional environment. Kipper (2014) performed palynologic analysis in samples taken from diamictites and laminated mudstones of unit 3 in localities 6 and 7 of the present study. The samples showed high amounts of reworked Devonian palynomorphs as well as Pennsylvanian guide miospores of the Ahrensisporites cristatus Biozone of Souza (2006) of Bashkirian/Moscovian age.

\subsubsection{Interpretation}

Striated/faceted clasts and dropstones indicate unequivocal glaciogenic source of sedimentsof unit 3. However, the absence of structures generated directly by ice (e.g., subglacial lineations), the intercalation of diamictites with mud-rich, thin-bedded facies and the presence of features indicative of mass flows like sandstone blocks and associated softsediment deformation, provides evidence that unit 3 was deposited in a glacially-influenced subaquatic setting. A marine influence can be postulated due to the presence of fossils indicative of brackish waters.

The thick-bedded, structureless sandstones with rip-up clasts and load structures constitute the deposits of high-density turbidity currents (cf., Lowe, 1982). The lack of lateral continuity of these turbidites among the examined outcrops, the erosive character of the flows indicated by rip-up clasts and bed amalgamation would indicate some degree of confinement of the turbidite system in the form of channels or ponds. The rhythmites with dropstones are interpreted as thin-bedded turbidites generated by low-density turbidity currents combined with deposition of ice-rafted debris from floating ice. The diamictites consist of masstransport deposits formed by the resedimentation of previously accumulated sediments on a subaqueous slope (e.g., Dykstra et al., 2006). This interpretation is supported by the following evidence: 1) presence of irregular or deformed blocks of other facies within the matrix; 2) concaveup scouring surfaces separating diamictite bodies; 3 ) heterogeneous matrix showing deformed and disrupted sand lenses or streaks; and 4) sandstone dykes probably formed due to upward sand remobilization (injection) from underlying, overpressured rhythmites.

Unit 3 can thus be interpreted as a glaciomarine slope complex (cf., Eyles et al., 1985) in which glacial influence is indirect and deposition is dominated by different categories of gravity-driven flows. The 

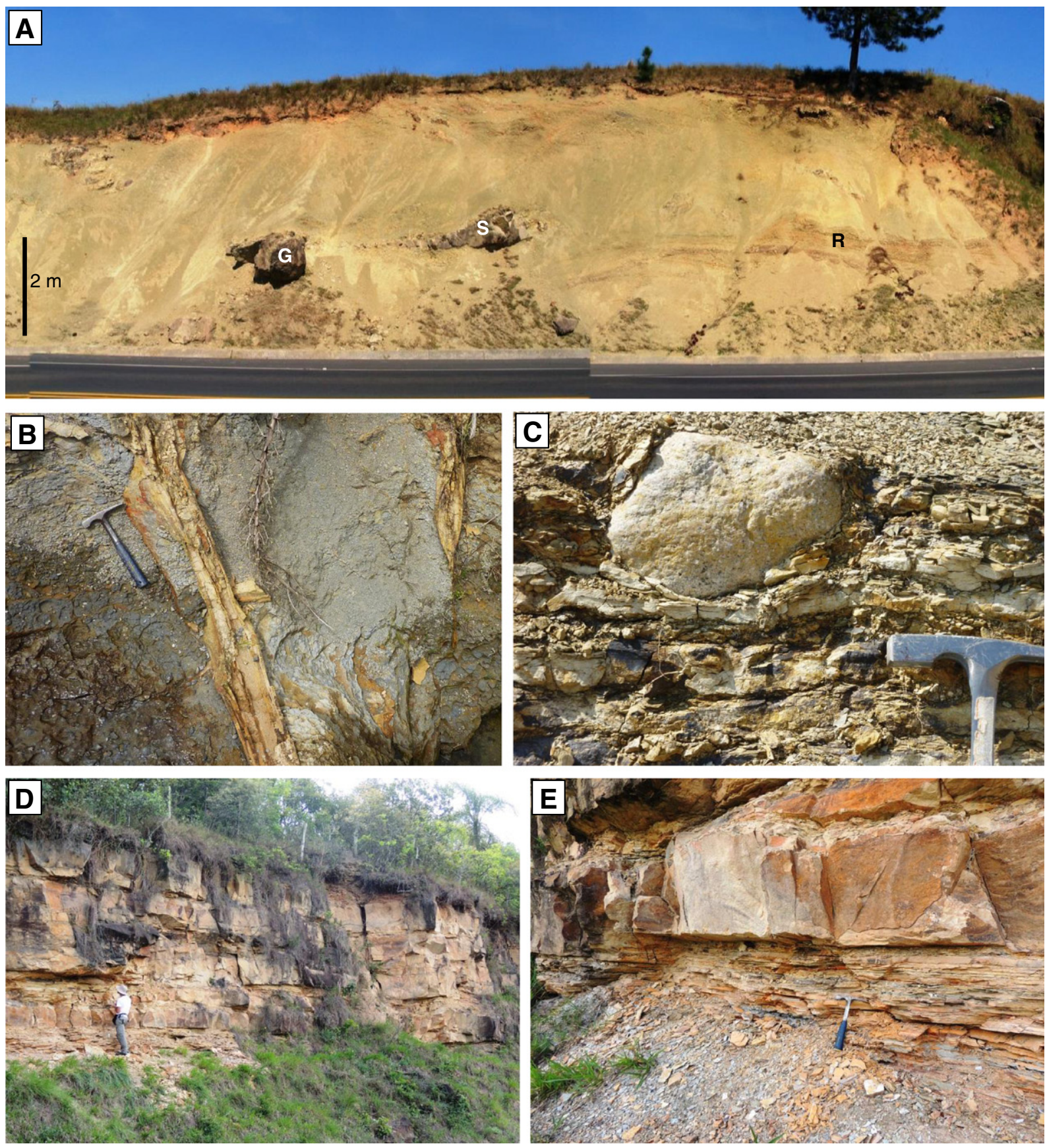

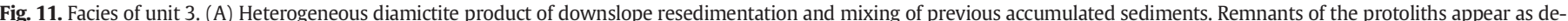

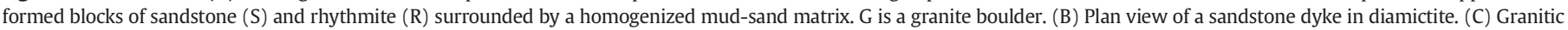
dropstone in rhythmite. (D) Tabular beds of massive sandstone (facies Sm) intercalated with rhythmite. (E) Same as D showing sharp-based massive sandstone above rhythmite.

muddy-matrix diamictites that are very common in this unit result from the progressive homogenization of sand, mud and gravel derived from more proximal areas close to the basin margin. Sandstone blocks are probably derived from the collapse of grounding-line fans or proglacial deltas located upslope. Gravel was probably supplied by both ice-rafting and meltwater jets from the ice margin.

\section{Interpreted glacial history}

The facies associations recognized are stacked in a vertical order that allows reconstruction of the local depositional history, its relationship with ice margin behavior and paleogeography. Four evolutionary stages are recognized, each characterized by distinct depositional patterns controlled by fluctuations of the ice margin and base level changes (Fig. 12). In Fig. 13 a schematic paleogeographic reconstruction for the studied area is presented, taking into account facies distribution and paleo ice-flow indicators for the different stages.

Stage I records a phase of ice advance across the study area, leading to erosion of the Devonian substrate and deposition of till in subglacial to ice-marginal settings (Fig. 12). Incorporation of sand by abrasion of the sandy Furnas Formation probably resulted in the high amount of sand observed in the tillites of unit 1-A. During this stage a warmbased glacier moved towards the north-northeast, as indicated by subglacial lineations oriented 2 to 12 mean azimuth on the pre-glacial substrate as well as on basal tillites. These tillites form a sheet-like deposit that pinches-out in the downflow direction and shows no significant 

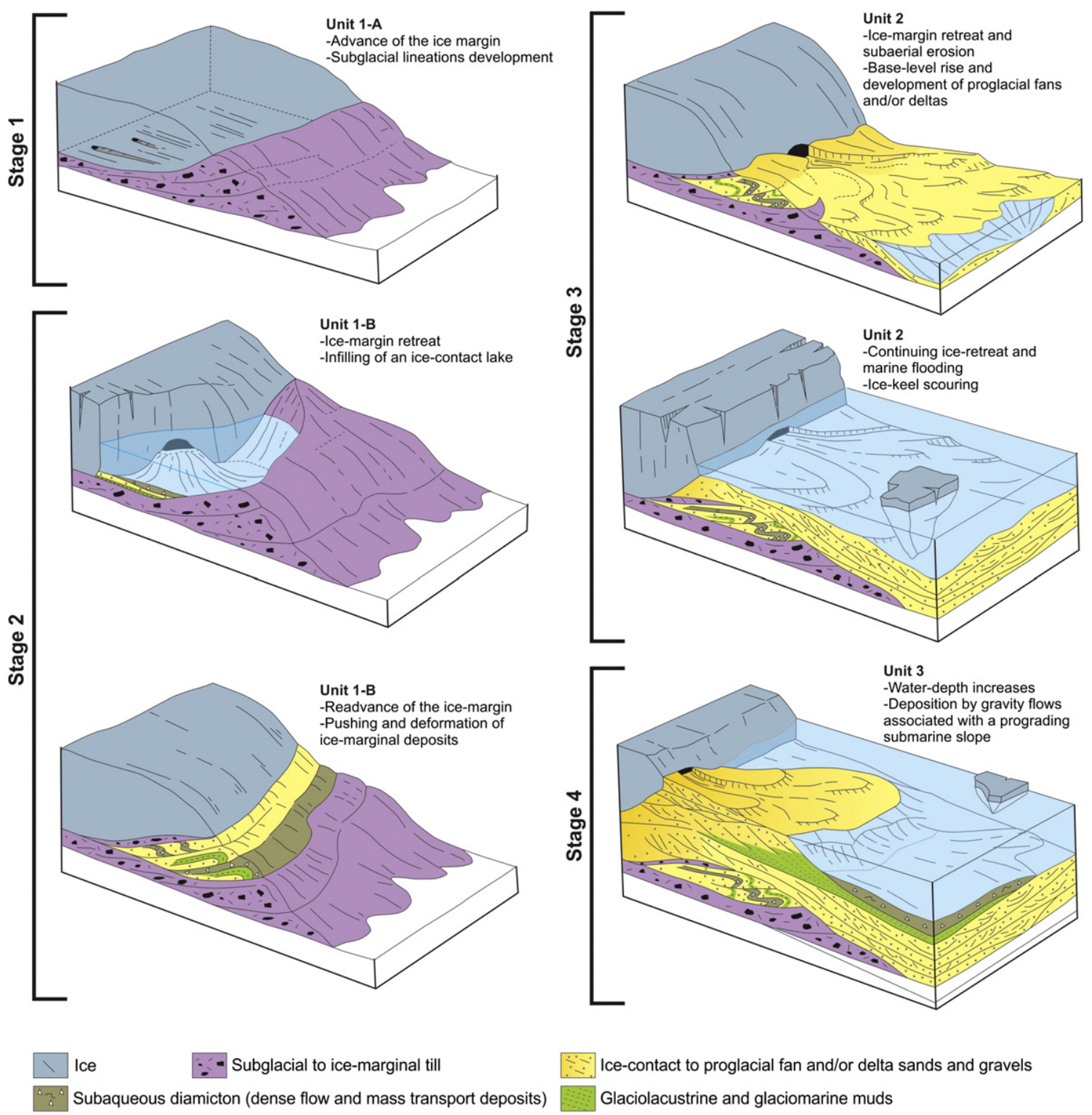

Fig. 12. Inferred paleodepositional settings for the four evolutionary stages recognized in the studied area.

strike-parallel thickness change, suggesting that ice flow was unconstrained by topography and that glacier flowed through a relatively flat land. Mechanisms of ice flow were sliding and soft-bed deformation as indicated by the presence of both subglacial lineations and foliation in the basal tillites.

The inferred maximum reach of ice margin during stage 1 coincides with the northernmost extent of unit 1-A, which are located in the Vila Velha area (Fig. 13). North of this area tillites are absent and subglacial lineations were not observed in the pre-glacial substrate. As a result, proglacial sandy deposits of unit 2 lie directly on Devonian rocks. The idea that the ice margin advanced within a water body (Trosdtorf et al., 2005a) is unlikely because tillites are not associated distally with subaqueous deposits like, for instance, fines with dropstones. A more probable paleoenvironmental scenario is that of an unconfined, terrestrial ice lobe similar to some large glaciers that currently flow from the Vatnajökull ice cap in Iceland and reach adjacent lowlands (Evans et al., 2007; Kjaer et al., 2008).

During stage II the ice margin retreated to the south and deposition was restricted to a relatively small, moraine-dammed, ice-contact lake that was filled essentially by meltwater-derived, coarse to fine grained sediments (unit 1-B). North of the moraine ridge, no deposition is recorded and the area probably remained exposed to subaerial erosion during that time. Readvances of the ice margin promoted pushing and deformation of the lake sediments, which is recorded by folds, thrust sheets and shear-modified lamination. Occasionally, the glacier advanced onto the lacustrine sediments, creating subglacial furrows on the soft bed and depositing a new sheet of subglacial till. Orientation of fold axis, thrust planes and subglacial lineations indicates that paleo ice-flow during stage II was towards the northwest (mean azimuth $=$ $328^{\circ}$ ), which means a shift of about $40^{\circ}$ in relation to stage I (Fig. 13). This change in ice flow direction is difficult to explain by assuming a continental scale ice sheet, suggesting thus a relatively smaller glacier and reinforcing the idea of an ice lobe flowing from adjacent highlands.

Stage III deposits lie on an unconformity that cut underlying subglacial and ice-marginal facies as well as the Devonian substrate. This surface developed due to subaerial meltwater erosion in the proglacial area during the retreat of the ice-margin farther to the southeast. Subsequent base level rise created accommodation space to be filled by proglacial sands in the form of outwash fans and deltas (unit 2). The fact that marine influence (Tasmanites and Botryoccocus) is recorded in mudstones higher in the section (unit 3 ) suggests that accommodation was created by relative sea level rise in response to deglaciation. The proglacial fans 


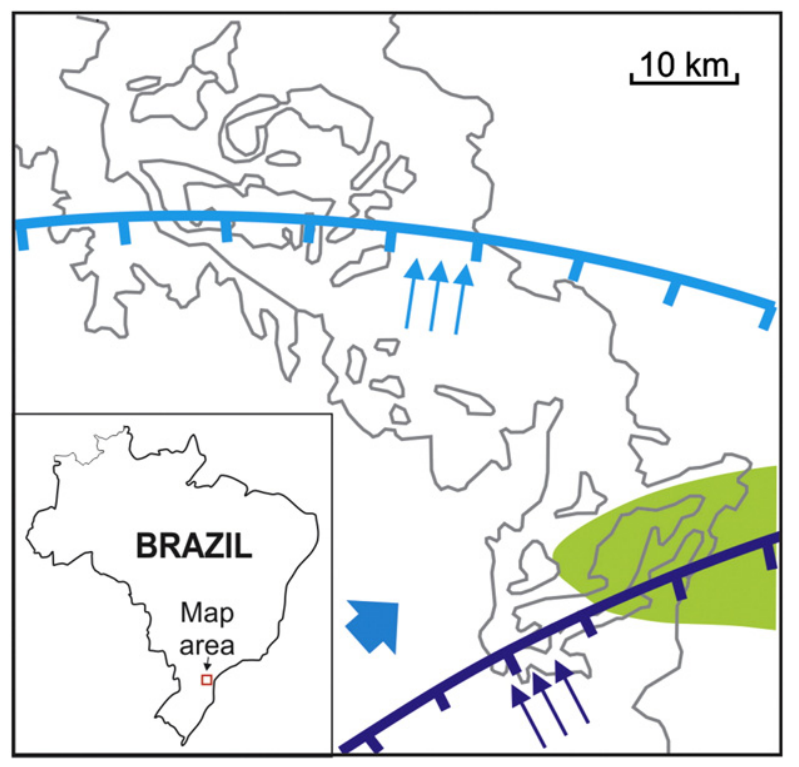

1 Maximum advance of the ice margin at stage I

\section{Maximum advance of the ice margin at stage II}

\section{MTI Ice flow at stage I}

Ice flow at stage II

Area occupied by an ice-contact lake during stage II

\section{Direction of marine incursions}

\section{Present limits of geologic units}

Fig. 13. Paleogeographic sketch for the studied area based on facies distribution and paleo ice-flow indicators for the different depositional stages.

and/or deltas were periodically flooded, as indicated by the high amounts of iceberg scours found in between sandstone beds and, occasionally, affected by catastrophic meltwater flows. Continuing retreat of the ice margin caused the backstepping of fans and/or deltas due to the upslope displacement of the sediment input point (e.g., Cheel and Rust, 1986; Brookfield and Martini, 1999). The existence of thrust faults affecting sandstone beds near the top of unit 2 points to a fluctuating ice margin located not far from the depositional site. Maximum deglacial transgression is achieved when dropstone-bearing shale and rhythmite are deposited above the fans and/or deltas. During stage IV, sedimentation took place in a relatively deeper subaqueous environment dominated by gravity-driven processes such as mass flow and turbidity currents. This sedimentation probably occurred associated with the progradation of a submarine slope complex subject to mass failure, which could have been the result of deceleration in the base level rise combined with high sedimentation rates associated with deglaciation in a more distal ice-marginal setting. A shallowing-upward stacking pattern is indicated by the cross-stratified, reddish sandstones of probable fluviodeltaic origin (Vila Velha sandstone) that occur stratigraphically above the deep-water deposits.

\section{Paleogeographic implications}

The studied stratigraphic interval is time-equivalent to the "deglaciation sequence" 1 described by Vesely and Assine (2006) in the Ventania area, northern Paraná State, which is located about $130 \mathrm{~km}$ north of the area of the present study. Both sections lie into the Biozone A. cristatus of Souza (2006), show similar facies associations, and have roughly the same vertical stacking pattern (Fig. 14). Although deposited during the same major glacial episode, the two areas were probably not affected by one single, large glacier, but rather by two different ice lobes (Fig. 15A), here called Southern Paraná Ice Lobe (SPIL) and Northern Paraná Ice Lobe (NPIL) by adapting the terminology used by Santos et al. (1996). The SPIL flowed to the north and, even at its maximum advance during stage I, it did not reach the Ventania area, which was located more distally to the north. Consequently, a different ice lobe (NPIL) is needed to explain the glacial sedimentation in Ventania, whose paleo ice-flow may be inferred as being to the WNW ( $289^{\circ}$ mean azimuth) based on paleocurrents measured from proglacial fan and/or delta sandstones (Vesely and Assine, 2006).

Both NPIL and SPIL were likely derived from an ice cap covering highlands east of the present outcrop belt of the Paraná Basin (Fig. 15B). The angular unconformity separating Carboniferous glacial rocks from the underlying Devonian units, along with the absence of those units to the east, are indicative of latest Devonian to pre-Pennsylvanian uplifting and erosion. This suggests the existence of a structural high east of the Paraná Basin, which probably elevated the land surface above the equilibrium line altitude leading to net snow accumulation and glacier development (Isbell et al., 2012). The Devonian-Carboniferous interface was a period of major tectonic movements over western Gondwana due to the EoHercynian orogeny that affected the Pacific protomargin of the supercontinent (López-Gamundí and Rossello, 1993). Tectonic stress related to this event propagated towards the cratonic area uplifting and tilting Devonian strata and, possibly, creating elevated land for the nucleation of ice masses during the Pennsylvanian (e.g., Isbell et al., 2012).

By restoring South America and Africa to their former positions in the Carboniferous (Fig. 15B), it can be observed that eastern Paraná Basin was situated close to the Huab and Kunene areas (western Namibia), where late Paleozoic glacial deposits are confined within paleovalleys that cut onto Precambrian rocks of the Damara belt (Frakes and Crowell, 1970; Visser, 1987). On the floors of these paleovalleys, subglacial landforms like roches mountonnées and crescentic gouges indicate glacial erosion of the Precambrian basement and a paleo ice-flow to the west towards the Paraná Basin (Frakes and Crowell, 1970). An age of $302 \mathrm{Ma}$ (Gzhelian) was obtained from radiometric dating of tuffs within the lowermost deglacial shale interval in the Ganigobis area, southern Namibia (Stollhofen et al., 2008). This is younger than the Bashkirian/Moscovian age indicated by palynomorphs found in rhythmites of the deglacial sequence 1 of the Itararé Group, which may suggest that when sedimentation started in eastern Paraná Basin the region of western Namibia was uplifted and glaciated. Later, the depositional area expanded to the east as a result of deglaciation and base level rise, leading sediments to fill the Namibian paleovalleys and to onlap the Precambrian basement (Fig. 15C).

Based on data discussed above, it is strongly suggestive that the Paraná Basin was connected to depositional areas of western Africa during the Pennsylvanian. Highlands located east of the basin margin (Windhoek highlands; Visser, 1987) were glaciated and supplied multiple and relatively small westward-flowing glaciers for the Paraná Basin. By consequence, the traditional view of a large polar ice sheet during the Late Paleozoic Ice Age is not suitable to explain glaciogenic deposition in eastern Paraná Basin. Our findings corroborate the idea of a topographicallycontrolled ice-spreading center in Namibia (Visser, 1987; Santos et al., 1996; Isbell et al., 2012) and reinforce the role of tectonic uplifting as a controlling factor for ice mass growth during the late Paleozoic.

\section{Conclusions}

Bashkirian/Moscovian glacial deposits are the oldest records of the Late Paleozoic Ice Age (LPIA) in eastern Paraná Basin. The stratigraphic analysis of these rocks in a small area of southern Brazil elucidates 
Ventania

(Vesely and Assine 2006)

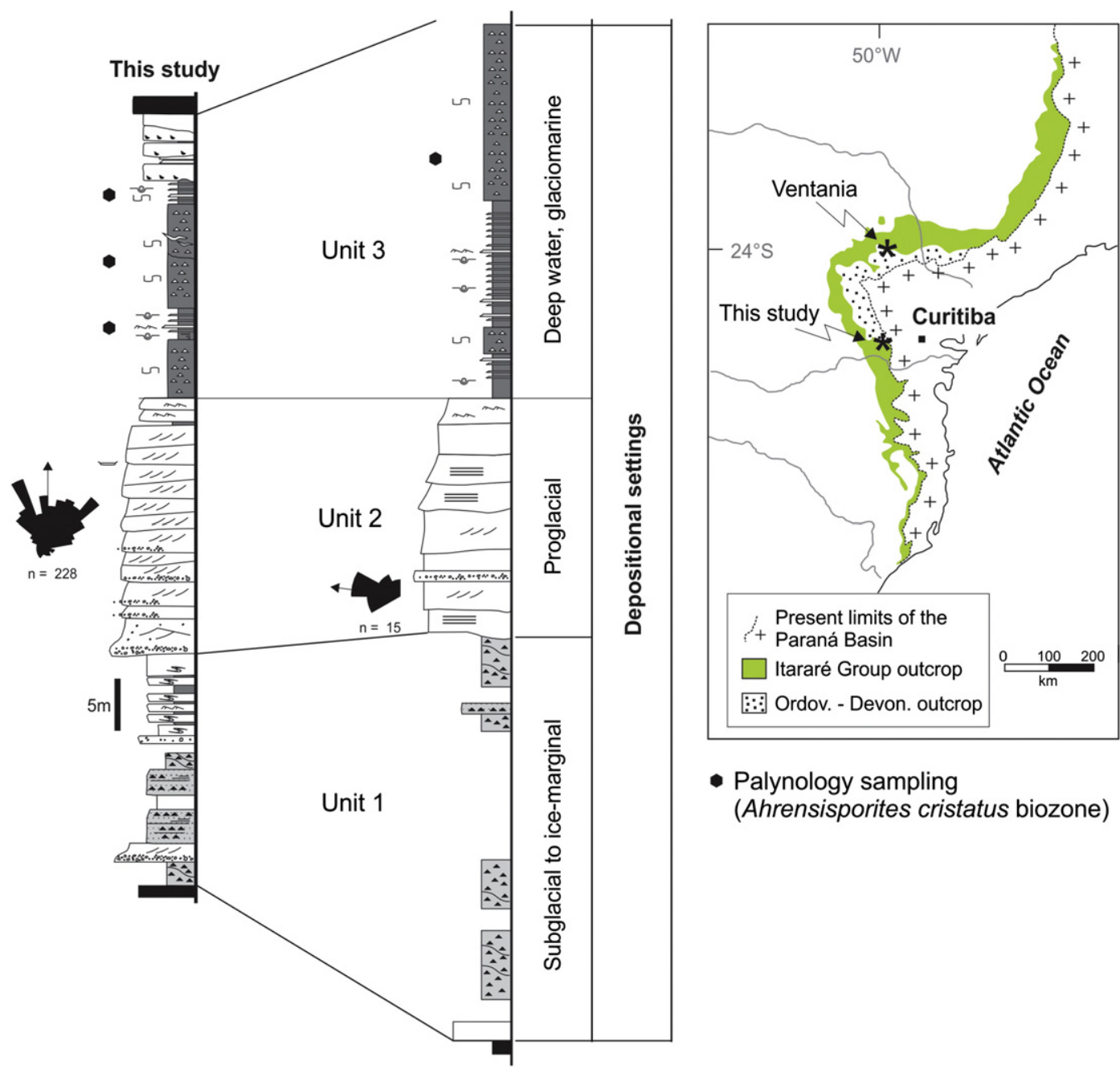

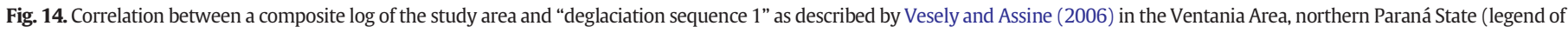

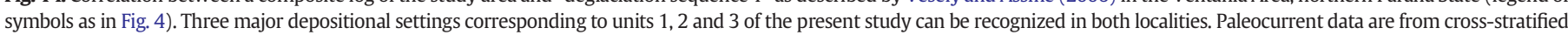
proglacial fan and/or delta sandstones (unit 2).

some important aspects of LPIA deposits in the intracratonic domain of western Gondwana as summarized below:

- The examined succession can be subdivided in four facies associations that record sedimentation in subglacial to glaciomarine settings associated with a recessional, fluctuating ice margin. Diamictites presenting shear fabric, resting on and overlain by subglacial lineations constitute basal to ice-marginal till deposits and indicate direct glacial influence on sedimentation associated with a north-northeastward flowing, wet-based glacier terminating on land.

- Glaciotectonic structures affecting deposits of ice-contact to proglacial fans and/or deltas allow the recognition of at least two other events of glacial advance towards the northwest. This indicates that a fluctuating ice margin was close to the depositional site during the early stages of deglaciation. Deglacial deposition was mainly subaqueous as revealed by density-flow and masstransport diamictites, rhythmites with dropstones and ice-keel scour marks, indicating flooding of the proglacial area accompanying the retreat of the ice margin. At least the middle and upper parts of the deglacial succession was deposited under marine influence.
- Different from other localities of western Gondwana such as the Argentinean Precordillera, the studied succession is not confined in paleovalleys or, at least, it was deposited in a poorly confined setting. This indicates deposition associated with a topographically unconstrained ice lobe instead of alpine-type glaciers.

- The limited downflow extent of till deposits and associated striated/ grooved pavements in the study area allows concluding that the ice margin did not advance far into the basin during the glacial maximum. Thus, the previous idea of a large ice mass occupying a broad area in the eastern side of the basin seems unlikely, but rather, equivalent sections that occur elsewhere across the outcrop belt were probably influenced by independent, smaller ice lobes.

- Results of the present study and comparisons with data from the literature corroborate that the most suitable source of ice to eastern Paraná Basin was tectonically-controlled highlands located in southwestern Africa. Several aspects support this hypothesis: 1) the reported examples of east-west oriented glacial paleovalleys and subglacial landforms in northwestern Namibia, 2) the angular unconformity separating Carboniferous deposits from the underlying Devonian units in eastern Paraná Basin and the absence of those early Paleozoic units in western Namibia, and 3) the fact that basal Carboniferous 

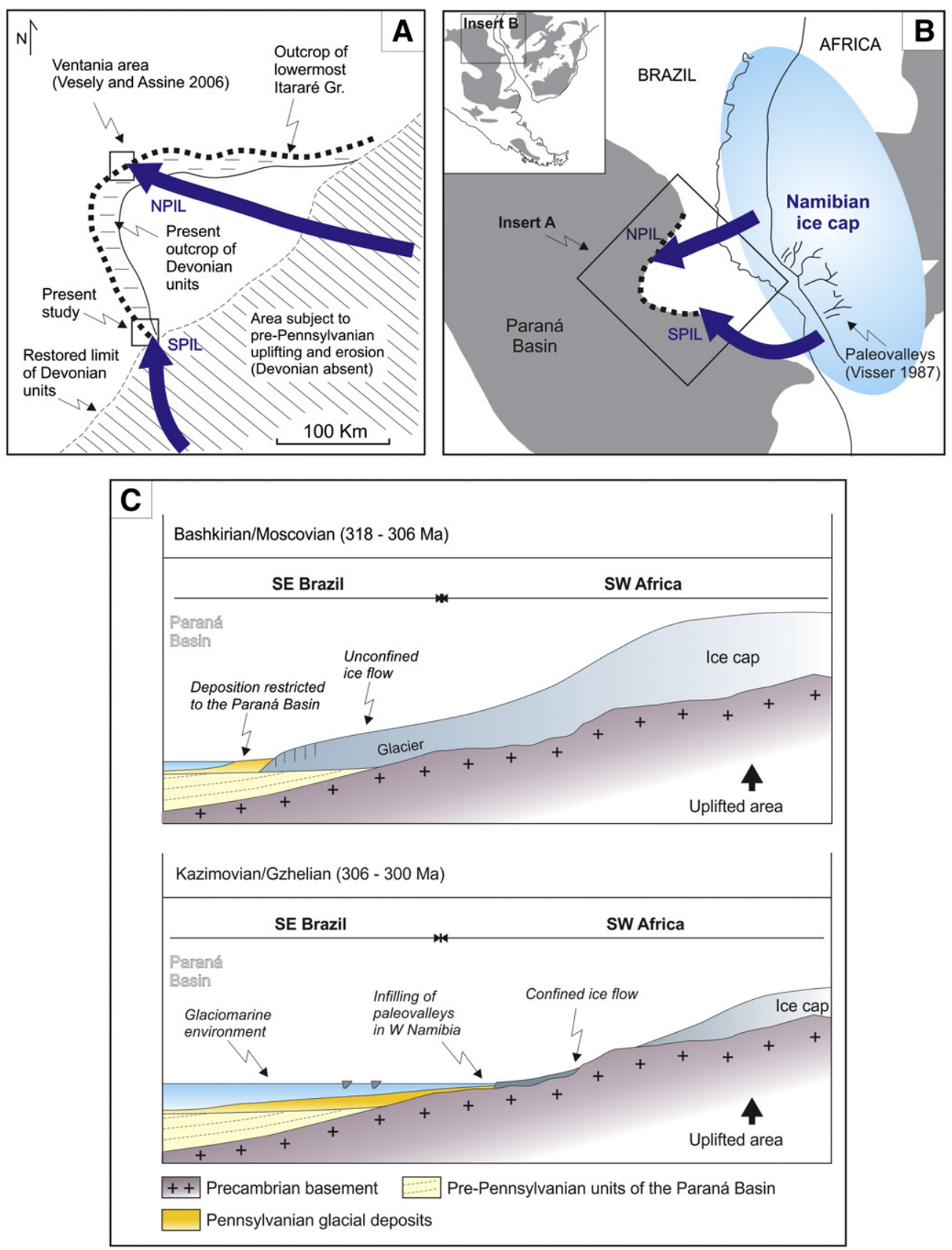

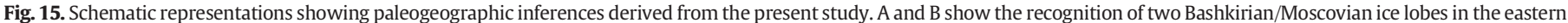

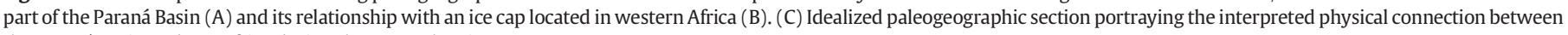
the Paraná Basin and SW Africa during the Pennsylvanian.

deposits of Namibia are younger than those from the Paraná Basin. By consequence, this conclusion does not support the model of a single polar ice sheet during the LPIA.

\section{Acknowledgements}

The authors thank the Brazilian Research Council (CNPq, grants 305108/2009-3, 401769/2010-0, 461650/2014-2 and 461628/2014-7) and the São Paulo State Foundation (FAPESP, grant 98/02183-3) for financial support to this research. We also thank Julia Wellner, an anonymous reviewer and editor Jasper Knight for constructive comments that improved the quality of the manuscript

\section{References}

Almeida, F.F.M., 1948. A "Roche Moutonnée" de Salto, estado de São Paulo. Boletim Geologia e Metalurgia 5, 112-118.

Assine, M.L. de Santa Ana, H., Verolavsky, G., 2010. Subglacial landforms, sedimentary facies and paleo-ice flow in the Permocarboniferous San Gregorio Formation, Chacoparanaense Basin, Uruguay (Abstract). 18th International Sedimentological Congress, Mendoza, 2010, Abstracts vol. 129.

Barbosa, O., 1940. Estrias produzidas por gelo permi-carbonífero. Mineração e Metalurgia $4,272-273$.

Bennett, M.R., Glasser, N.F., 2009. Glacial geology: Ice Sheets and Landforms. Wiley-Blackwell, New York (385 pp.).

Bigarella, J.J., Salamuni, R., Fuck, R.A., 1967. Striated surfaces and related features developed by Gondwana ice sheets (State of Paraná, Brazil). Palaeogeography, Palaeoclimatology, Palaeoecology 3, 265-276.

Boulton, G.S., 1976. The origin of glacially fluted surfaces - observations and theory. Journal of Glaciology 17, 287-309.

Boulton, G.S., 1979. Processes of glacial erosion on different substrata. Journal of Glaciology $22,15-38$. 
Boulton, G.S., 1986. Push moraines and glacier-contact fans in marine and terrestrial environments. Sedimentology 33, 677-698.

Brookfield, M.E., Martini, I.P., 1999. Facies architecture and sequence stratigraphy in glacially influenced basins: basic problems and water-level/glacier input-point controls (with an example from the Quaternary of Ontario, Canada). Sedimentary Geology 123, 183-197.

Catuneanu, O., Wopfner, H., Eriksson, P.G., Cairncross, B., Rubidge, B.S., Smith, R.M.H., Hancox, P.J., 2005. The Karoo basins of south-central Africa. Journal of African Earth Sciences 43, 211-253.

Cheel, R.J., Rust, B.R., 1986. A sequence of soft-sediment deformation (dewatering) structures in Late Quaternary subaqueous outwash near Ottawa, Canada. Sedimentary Geology 47, 77-93.

Dionne, J.C., 1969. Tidal flat erosion by ice at La Pocatière, Saint Lawrence Estuary. Journal of Sedimentary Petrology 39, 1174-1181.

Dykstra, M., Kneller, B.C., Milana, J.P., 2006. Deglacial and postglacial sedimentary architecture in a deeply incised paleovalley-paleofjord-The Pennsylvanian (late Carboniferous) Jejenes Formation, San Juan, Argentina. Geological Society of America Bulletin $118,913-937$.

Evans, D.J.A., Phillips, E.R., Hiemstra, J.F., Auton, C.A., 2006. Subglacial till: formation, sedimentary characteristics and classification. Earth-Science Reviews 78, 115-176.

Evans, D.J.A., Twigg, D.R., Rea, B.R., Shand, M., 2007. Surficial geology and geomorphology of the Brúarjökull surging glacier landsystem. Journal of Maps 2007, 349-367.

Eyles, C.H., Eyles, N., 2000. Subaqueous mass flow origin for Lower Permian diamictites and associated facies of the Grant Group, Barbwire Terrace, Canning Basin, Western Australia. Sedimentology 47, 343-356.

Eyles, C.H., Eyles, N., Miall, A.D., 1985. Models of glaciomarine sedimentation and their application to the interpretation of ancient glacial sequences. Palaeogeography Palaeoclimatology Palaeoecology 51, 15-84.

Eyles, N., Eyles, C.H., França, A.B., 1993. Glaciation and tectonics in an active intracratonic basin: the late Paleozoic Itarare Group, Paraná Basin, Brazil. Sedimentology 40, 1-25.

Eyles, N., Eyles, C.H., Woodworth-Lynas, C.M.T., Randall, T.A., 2005. The sedimentary record of drifting ice (early Wisconsin Sunnybrook deposit) in an ancestral icedammed Lake Ontario, Canada. Quaternary Research 63, 171-181.

Resolving the Late Paleozoic Ice Age in Time and Space. In: Fielding, C.R., Frank, T.D., Isbell, J.L. (Eds.), 441. Geological Society of America, Special Publication.

Flint, R.F., Sanders, J.E., Rodgers, J., 1960. Diamictite, a substitute term for symmictite. Geological Society of America Bulletin 71, 1809.

Frakes, L.A., Crowell, J.C., 1970. Late Paleozoic glaciation: II, Africa exclusive of the Karoo Basin. Geological Society of America Bulletin 81, 2261-2286.

França, A.B., Potter, P.E., 1991. Stratigraphy and reservoir potential of glacial deposits of the Itararé Group (Carboniferous-Permian), Paraná Basin, Brazil. American Association of Petroleum Geologists Bulletin 75, 62-85.

França, A.B., Winter, W.R., Assine, M.L., 1996. Arenitos Lapa-Vila Velha: um modelo de trato de sistemas subaquosos canal-lobos sob influência glacial, Grupo Itararé (C-P), Bacia do Paraná. Revista Brasileira de Geociencias 26, 43-56.

Gesicki, A.L.D., Riccomini, C., Boggiani, P.C., 2002. Ice flow direction during late Paleozoic glaciation in western Paraná Basin, Brazil. Journal of South American Earth Sciences 14, 933-939.

Ghienne, J.F., Girard, F., Moreau, J., Rubino, J.L., 2010. Late Ordovician climbing-dune crossstratification: a signature of outburst floods in proglacial outwash environments? Sedimentology 57, 1175-1198.

Gravenor, C.R., Rocha-Campos, A.C., 1983. Patterns of late Paleozoic glacial sedimentation on the southeast side of Paraná Basin, Brazil. Palaeogeography Palaeoclimatology Palaeoecology 43, 1-39.

Gulbranson, E.L., Isbell, J.L., Montañez, I.P., Limarino, C.O., Marenssi, S.A., Meyer, K., Hull, C., 2013. Reassessment of mid-Carboniferous glacial extent in southwestern Gondwana (Rio Blanco Basin, Argentina) inferred from paleo-mass transport of diamictites. Gondwana Research 25, 1369-1379.

Hart, J.K., Boulton, G.S., 1991. The interrelation of glaciotectonic and glaciodeposicional processes within the glacial environment. Quaternary Science Reviews 10, 335-350.

Hart, J.K., Roberts, D.H., 1994. Criteria to distinguish between subglacial glaciotectonic and glaciomarine sedimentation, I. Deformation styles and sedimentology. Sedimentary Geology 91, 191-213.

Hart, J.K., Smith, B., 1997. Subglacial deformation associated with fast ice flow, from the Columbia Glacier, Alaska. Sedimentary Geology 111, 177-197.

Henry, L.C., Isbell, J.L., Limarino, C.O., 2014. The late Paleozoic El Imperial Formation, western Argentina: glacial to post-glacial transition and stratigraphic correlations with arc-related basins in southwestern Gondwana. Gondwana Research $25,1380-1395$

Holz, M., França, A.B., Souza, P.A., Iannuzzi, R., Rohn, R., 2010. A stratigraphic chart of the late Carboniferous/Permian succession of the eastern border of the Paraná Basin, Brazil, South America. Journal of South American Earth Sciences 29, 381-399.

Hornung, J.J., Asprion, U., Winsemann, J., 2007. Jet-efflux deposits of a subaqueous icecontact fan, glacial Lake Rinteln, northwestern Germany. Sedimentary Geology 193, 167-192.

Isbell, J.L., 2010. Environmental and paleogeographic implications of glaciotectonic deformation of glaciomarine deposits within Permian strata of the Metschel Tillite, southern Victoria Land, Antarctica. In: López-Gamundí, O.R., Buatois, L.A. (Eds.), Late Paleozoic Glacial Events and Postglacial Transgressions in Gondwana. Geological Society of America Special Paper 468, pp. 81-100.

Isbell, J.L., Henry, L.C., Gulbranson, E.L., Limarino, C.O., Fraiser, M.L., Koch, Z.J., Ciccioli, P.L., Dineen, A.A., 2012. Glacial paradoxes during the late Paleozoic ice age: evaluating the equilibrium line altitude as a control on glaciation. Gondwana Research 22, 1-19.

Kipper, F., 2014. Palinoestratigrafia da porção inferior do Grupo Itararé (Carbonífero) no sudeste do estado do Paraná. Universidade Federal do Paraná, Curitiba, Brazil (MSc thesis).
Kjaer, K.H., Korsgaard, N.J., Schomacker, A., 2008. Impact of multiple glacier surges: a geomorphological map from Brúarjökull, East Iceland. Journal of Maps 4, 5-20.

Kneller, B., Milana, J.P., Buckee, C., Al Jaidi, O., 2004. A depositional record of deglaciation in a paleofjord (Late Carboniferous [Pennsylvanian] of San Juan Province, Argentina): the role of catastrophic sedimentation. Geological Society of America Bulletin 116, 348-367.

Limarino, C.O., Tripaldi, A., Marenssi, S., Fauqué, L., 2006. Tectonic, sea-level, and climatic controls on late Paleozoic sedimentation in the western basins of Argentina. Journal of South American Earth Sciences 22, 205-226.

Limarino, C.O., Césari, S.N., Spalletti, L.A., Taboada, A.C., Isbell, J.L., Geuna, S., Gulbranson, E.L., 2014a. A paleoclimatic review of southern South America during the late Paleozoic: a record from icehouse to extreme greenhouse conditions. Gondwana Research $25,1396-1421$.

Limarino, C.O., Alonso-Muruaga, P.J., Ciccioli, P.L., Loinaze, V.S.P., Césari, S.N., 2014b. Stratigraphy and palynology of a late Paleozoic glacial paleovalley in the Andean Precordillera, Argentina. Palaeogeography Palaeoclimatology Palaeoecology 412, $223-240$.

Lønne, I., 1995. Sedimentary facies and depositional architecture of ice-contact glaciomarine systems. Sedimentary Geology 98, 13-43.

López-Gamundí, O.R., Buatois, L.A. (Eds.), 2010. Late Paleozoic Glacial Events and Postglacial Transgressions in Gondwana. Geological Society of America Special Paper 468.

López-Gamundí, O., Martinez, M., 2000. Evidence of glacial abrasion in the Calingasta -Uspallata and western Paganzo basins, mid-Carboniferous of western Argentina. Palaeogeography Palaeoclimatology Palaeoecology 159, 145-165.

López-Gamundí, O., Rossello, E.A., 1993. Devonian-Carboniferous unconformity in Argentina and its relation to Eo-Hercynian orogeny in southern South America. Geologische Rundschau 82, 136-147.

Lowe, D.R., 1982. Sediment gravity flows: II. Depositional models with special reference to the deposits of high-density turbidity currents. Journal of Sedimentary Petrology 52 279-297.

Maack, R.A., 1946. Geologia e geografia da região de Vila Velha (Paraná) e considerações sobre a glaciação carbonífera no Brasil. Arquivos do Museu Paranaense 5, 1-305.

Miall, A.D., 1985. Architectural-element analysis: a new method of facies analysis applied to fluvial deposits. Earth Science Reviews 22, 261-308.

Milani, E.J., 2004. Comentários sobre a origem e evolução tectônica da Bacia do Paraná. In: Mantesso-Neto, V., Bartorelli, A., Carneiro, C.D.R., Brito-Neves, B.B. (Eds.), Geologia do Continente Sul-Americano: Evolução da Obra de Fernando Flávio Marques de Almeida. Editora Beca, São Paulo, pp. 266-279.

Mulder, T., Alexander, J., 2001. The physical character of subaqueous sedimentary density flows and their deposits. Sedimentology 48, 269-299.

Mutti, E., Davoli, G., Tinterri, R., Zavala, C., 1996. The importance of fluvio-deltaic systems dominated by catastrophic flooding in tectonically active basins. Memorie di Scienze Geologiche 48, 233-291.

O'Brien, P.E., Christie-Blick, N., 1992. Glacially grooved surfaces in the Grant Group, Grant Range, Canning Basin and the extent of late Palaeozoic Pilbara ice sheets. Journal of Australian Geology and Geophysics 13, 87-92.

Powell, R.D., 1990. Glacimarine processes at grounding-line fans and their growth to icecontact deltas. In: Dowdeswell, J.A., Scourse, J.D. (Eds.), Glacimarine environments: processes and sediments. Geological Society of London Special Publication 53, pp. 53-73.

Rattas, M., Kalm, V., 2004. Glaciotectonic deformation patterns in Estonia. Geological Quarterly 48, 15-22.

Roberts, D.H., Hart, J.K., 2005. The deforming bed characteristics of a stratified till assemblage in north East Anglia, UK: investigating controls on sediment rheology and strain signatures. Quaternary Science Reviews 24, 123-140.

Rocha-Campos, A.C., 1967. The Tubarão Group in the Brazilian portion of the Paraná Basin. In: Bigarella, J.J., Becker, R.D., Pinto, I.D. (Eds.), Problems in Brazilian Gondwana Geology Curitiba. Universidade Federal do Paraná, pp. 27-102.

Rocha-Campos, A.C., Rösler, O., 1978. Late Paleozoic faunal and floral sucessions in Paraná Basin, southeastern Brazil. Instituto de Geociências da Universidade de São Paulo Boletim 9 pp. 1-16.

Rocha-Campos, A.C., dos Santos, P.R., Canuto, J.R., 2008. Late Paleozoic glacial deposits of Brazil: Paraná Basin. In: Fielding, C.R., Frank, T.D., Isbell, J.L. (Eds.), Resolving the Late Paleozoic Ice Age in Time and Space: Geological Society of America Special Paper. 441, pp. 97-114.

Rocha-Campos, A.C., Machado, L.C.R., Santos, P.R., Canuto, J.R., Castro, J.C., 1988. Pavimento estriado da glaciação Neo-Paleozóica em Alfredo Wagner, SC, Brasil. Instituto de Geociências da Universidade de São Paulo, Boletim 19 pp. 39-46.

Russell, H.A.J., Arnott, R.W.C., 2003. Hydraulic-jump and hyperconcentrated-flow deposits of a glacigenic subaqueous fan: Oak Ridges moraine, Southern Ontario, Canada. Journal of Sedimentary Research 73, 887-905.

Santos, P.R., Rocha-Campos, A.C., Canuto, J.R., 1996. Patterns of late Palaeozoic deglaciation in the Paraná Basin, Brazil. Palaeogeography Palaeoclimatology Palaeoecology $125,165-184$.

Schneider, R.L., Muhlmann, H., Tommasi, E., Medeiros, R.A., Daemon, R.A., Nogueira, A.A 1974. Revisão estratigráfica da Bacia do Paraná. Anais do $28^{\circ}$ Congresso Brasileiro de Geologia 1. Sociedade Brasileira de Geologia, Porto Alegre, pp. 41-65.

Souza, P.A., 2000. Palinobioestratigrafia do Subgrupo Itararé. Carbonífero/Permiano, na porção nordeste da Bacia do Paraná (SP/PR, Brasil). Universidade de São Paulo, São Paulo, Brazil (PhD Thesis).

Souza, P.A., 2006. Late Carboniferous palynostratigraphy of the Itararé Subgroup, northeastern Paraná Basin, Brazil. Review of Palaeobotany and Palynology 38, 9-29.

Spalletti, L.A., Limarino, C.O., Geuna, S., 2010. The late Palaeozoic of Western Gondwana: new insights from South American records. Geologica Acta 8, 341-347.

Stark, D., del Papa, C., 2006. The northwestern Argentina Tarija Basin: stratigraphy, depositional systems, and controlling factors in a glaciated basin. Journal of South American Earth Sciences 22, 169-184. 
Stollhofen, H., Werner, M., Stanistreet, I.G., Armstrong, R.A., 2008. Single-zircon U-Pb dating of Carboniferous-Permian tuffs, Namibia and the intercontinental deglaciation cycle framework. In: Fielding, C.R., Frank, T.D., Isbell, J.L. (Eds.), Resolving the Late Paleozoic Ice Age in Time and Space. Geological Society of America Special Publication 441, pp. 83-96.

Tomazelli, L.J., Soliani Jr., E., 1997. Sedimentary facies and depositional environments related to Gondwana glaciations in Batovi and Suspiro regions, Rio Grande do Sul, Brazil. Journal of South American Earth Sciences 10, 295-303.

Trosdtorf Jr., I., Assine, M.L., Vesely, F.F., Rocha-Campos, A.C., Santos, P.R., Tomio, A., 2005a. Glacially striated, soft sediment surfaces on late Paleozoic tillite at São Luiz do Purunã, PR. Anais da Academia Brasileira de Ciências 77, 367-378.

Trosdtorf Jr., I., Rocha-Campos, A.C., Santos, P.R., Tomio, A., 2005b. Origin of late Paleozoic, multiple, glacially striated surfaces in northern Paraná Basin (Brazil): some implications for the dynamics of the Paraná glacial lobe. Sedimentary Geology 181, 59-71.

Van der Meer, J.J.M., 1997. Short-lived streamlined bedforms (annual small flutes) forme under clean ice, Turtmann Glacier, Switzerlan. Sedimentary Geology 111, 107-118.

Van der Meer, J.J.M., Menzies, J., Rose, J., 2003. Subglacial till: the deforming glacier bed. Quaternary Science Reviews 22, 1659-1685.

Van der Wateren, F.M., 1994. Proglacial subaquatic outwash fan and delta sediments in push moraines: indicators of subglacial meltwater activity. Sedimentary Geology 91, 145-152.

Vesely, F.F., Assine, M.L., 2002. Superfícies estriadas em arenitos do Grupo Itararé produzidas por gelo flutuante, sudeste do Estado do Paraná. Revista Brasileira de Geociencias 32, 587-594
Vesely, F.F., Assine, M.L., 2006. Deglaciation sequences in the Permo-Carboniferous Itararé Group Paraná Basin, southern Brazil. Journal of South American Earth Sciences 22, $156-168$.

Vesely, F.F., Assine, M.L., 2014. Ice-keel scour marks in the geological record: evidence from Carboniferous soft-sediment striated surfaces in the Paraná Basin, southern Brazil. Journal of Sedimentary Research 84, 26-39.

Visser, J.N.J., 1987. The palaeogeography of part of southwestern Gondwana during the Permo-Carboniferous glaciation. Palaeogeography, Palaeoclimatology, Palaeoecology 61, 205-219.

Visser, J.N.J., 1990. Glacial bedforms at the base of the Permo-Carboniferous Dwyka Formation along the western margin of the Karoo Basin, South Africa. Sedimentology 37, 231-245.

Visser, J.N.J., 1996. Controls on Early Permian shelf deglaciation on the Karoo Basin of South Africa. Palaeogeography Palaeoclimatology Palaeoecology 125, 129-140.

Visser, J.N.J., 1997. Deglaciation sequences in the Permo-carboniferous Karoo and Kalahari basins of southern Africa: a tool in the analysis of cyclic glaciomarine basin fills. Sedimentology 44, 507-522.

Von Brunn, V., 1996. The Dwyka Group in the northern part of Kwazulu/Natal, South Africa: sedimentation during late Paleozoic deglaciation. Palaeogeography Palaeoclimatology Palaeoecology 125, 141-163.

Woodworth-Lynas, C.M.T., Dowdeswell, J.D., 1994. Soft-sediment striated surfaces and massive diamicton facies produced by floating ice. In: Deynoux, M., Miller, J.M.J., Domack, E.W., Eyles, N., Fairchild, I.J., Young, G.M. (Eds.), Earth's Glacial Record. Cambridge University Press, Cambridge, U.K., pp. 241-259. 